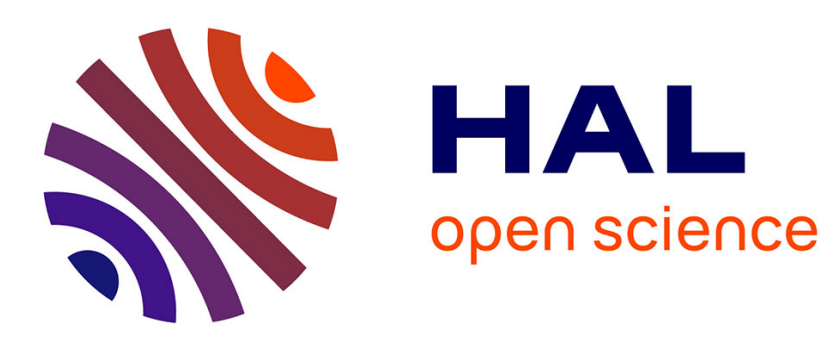

\title{
Linking Top-Down and Bottom-UP Models for Climate Policy Analysis The Case of China
}

\author{
Govinda Timilsina, Jun Pang, Xi Yang
}

\section{To cite this version:}

Govinda Timilsina, Jun Pang, Xi Yang. Linking Top-Down and Bottom-UP Models for Climate Policy

Analysis The Case of China. 2021. hal-03503532

\section{HAL Id: hal-03503532 \\ https://hal.science/hal-03503532}

Preprint submitted on 28 Dec 2021

HAL is a multi-disciplinary open access archive for the deposit and dissemination of scientific research documents, whether they are published or not. The documents may come from teaching and research institutions in France or abroad, or from public or private research centers.
L'archive ouverte pluridisciplinaire HAL, est destinée au dépôt et à la diffusion de documents scientifiques de niveau recherche, publiés ou non, émanant des établissements d'enseignement et de recherche français ou étrangers, des laboratoires publics ou privés. 


\title{
Policy Research Working Paper 8905
}

\section{Linking Top-Down and Bottom-UP Models for Climate Policy Analysis}

\author{
The Case of China
}

\author{
Govinda Timilsina \\ Jun Pang \\ Xi Yang
}

\section{WORLD BANK GROUP}

Development Economics

Development Research Group

June 2019 
Policy Research Working Paper 8905

\begin{abstract}
Top-down economic models, such as computable general equilibrium models, are the common tools to assess the economic impacts of climate change policies. However, these models are incapable of representing the detailed technological characteristics of the sources of greenhouse gas emissions. The economic impacts measured by the topdown economic models are likely to be overestimated. This study attempts to quantify the overestimation by measuring the economic impacts linking the top-down model with a
\end{abstract}

bottom-up engineering model for the energy sector. The study uses meeting China's pledges under the Paris Agreement for testing this hypothesis. The study shows that the economic impacts measured by the stand-alone top-down model are almost three times as high as those resulting from the model after linking it with the bottom-up model. However, the findings are sensitive to the assumptions and existing or planned policies on energy technologies considered in the bottom-up model.

This paper is a product of the Development Research Group, Development Economics. It is part of a larger effort by the World Bank to provide open access to its research and make a contribution to development policy discussions around the world. Policy Research Working Papers are also posted on the Web at http://www.worldbank.org/prwp. The authors may be contacted at gtimilsina@worldbank.org.

The Policy Research Working Paper Series disseminates the findings of work in progress to encourage the exchange of ideas about development issues. An objective of the series is to get the findings out quickly, even if the presentations are less than fully polished. The papers carry the names of the authors and should be cited accordingly. The findings, interpretations, and conclusions expressed in this paper are entirely those of the authors. They do not necessarily represent the views of the International Bank for Reconstruction and Development/World Bank and its affliated organizations, or those of the Executive Directors of the World Bank or the governments they represent. 


\title{
Linking Top-Down and Bottom-UP models for Climate Policy Analysis: The Case of China ${ }^{1}$
}

\author{
Govinda Timilsina, Jun Pang and Xi Yang ${ }^{2}$
}

Key Words: To-down and bottom-up linkage, energy modeling, macroeconomic impacts, computable general equilibrium modeling, Power sector planning, China

JEL Classification: C68, Q43

\footnotetext{
${ }^{1}$ The authors would like to thank Dai Hanchang, Christophe de Gouvello, Bekele Debele, Dafei Huang, Yanqin Song,Xi Xiangyang, Feng Xiagzhao, Mao Xianqiang, Liu Qiang, Duan Hongbo and Fu Guanjan for their valuable comments and suggestions. The views and interpretations are of authors and should not be attributed to the World Bank Group and the organizations they are affiliated with. We acknowledge World Bank's Research Support Grant (RSB) for financial support.

${ }^{2}$ Govinda Timilsina (gtimilsina@worldbank.org) is a Senior Economist at the Development Research Group, World Bank. Jun Pang (pangjun2005@ruc.edu.cn) is a Professor at the School of Environment and Natural Resources, Renmin University, Beijing, China.). Xi Yang (sissiyang_tsinghua@foxmail.com) is an Associate Professor at China University of Petroleum Beijing, China.
} 


\section{Linking Top-Down and Bottom-UP models for Climate Policy Analysis: The Case of China}

\section{Introduction}

Computable general equilibrium (CGE) and other macroeconomic models are the most common analytical tools to analyze the economics of climate change policies (see, e.g., Timilsina, 2018; Edenhofer et al. 2006; De la Chesnaye and Weyant, 2006; Weyant, 1999). These models are referred to as top-down models in the literature because they represent economic agents (e.g., productive sectors, households, governments) in an aggregated or representative manner. There are multiple reasons behind the varying estimates of economic costs of meeting China's NDC. The main limitation of top-down models is that they are incapable of incorporating policies specific to a sector, sub-sector or technology because those models are not capable of explicitly representing characteristics of those sectors, sub-sectors and technologies. For example, most top-down models represent electricity generation as a single technology. However, electricity generation includes different technologies (e.g., hydro, nuclear, solar, wind, coal, oil, gas). These technologies are highly different in terms of their labor, capital, fuel and material intensities. Capturing the difference is further important in climate change policy analysis because while coal-based power generation is highly emission intensive, renewables (e.g., hydro, solar, wind, geothermal) and nuclear do not produce any direct emissions. Similarly, heat rate (i.e., energy input rate) and emission rates are different for various industrial applications and automobiles. Those characteristics cannot be incorporated in CGE models as a CGE model represents a sector aggregated at 2 to 3-digit International standards for industrial classification (ISIC) and automobiles are aggregated in transportation or road transportation sectors. Not only is the CGE model not capable of representing physical characteristics of technologies, it also misses economic characteristics of these technologies.

Models that can represent arrays of technologies are very common in the energy economics literature. These models are referred to as bottom-up models. These models represent the physical and economic characteristics of technologies used in both energy supply chains and also energy utilization streams. These models are good in producing energy demand forecasts and also energy supply mix to meet the projected demand. These models are also used to estimate the cost of GHG mitigation or the marginal cost of GHG abatement. However, these 
models are not capable of estimating economy-wide impacts of energy or climate change policies.

Researchers are working on linking the top-down models with bottom-up models so that they can capture technological details and at the same time produce economy-wide impacts of a policy. There are two ways to link top-down CGE models with bottom-up sectoral models. One way is hard linking of these two models which refers to directly reflecting detailed subsectors/technologies in the top-down model by disaggregating economic sectors/technologies in the social accounting matrices (SAMs), the main database for calibrating a CGE model. The resulting model is also referred to as a hybrid model (e.g., Dai et al. 2011; Dai et al. 2016; Dai and Mischke, 2014; and Schafer and Jacoby, 2006). However, the hard linkage is quite complicated due to the lack of data, and it is applicable only for limited technology, such as electricity generation. Studies such as Timilsina et al. (2018), Timilsina and Shretha (2006), Timilsina and Landis (2014) have applied this approach to model impacts of substitution of fossil fuel-based electricity generation with renewable energy-based electricity generation. The second way is understood as soft linking. It is an iterative process where the top-down model is run first to project key variables such as sectoral outputs and value-added, commodity prices and so on. These variables are then used in the bottom-up model, which then produces optimal energy supply or electricity supply systems depending upon whether the bottom-up model is an energy sector model or electricity model. The results from the bottom-up the model are then fed into the top-down model. A few rounds of iterations are carried out until both models converge. If the modeling assumptions are consistent between the two models, iteratively running the two soft-linked models can lead to a consistent equilibrium (Böhringer and Rutherford 2008, 2009). Several studies, such as Bukowski and Kowal (2010), Drouet et al. (2005), Schafer and Jacoby (2006), World Bank (2014), World Bank (2016), have applied this approach. In this study, we adopt the soft-linking approach to link the energy sector bottom-up model, TIMES, with a top-down CGE model.

As discussed above, the linkage of top-down models with bottom-up models is crucial for a more precise assessment of the economic costs of climate change measures and policies. However, there exists no study that illustrates how much the results of policy analysis would be different if the two models are linked and not linked. This study aims to illustrate the difference in the assessment of economic costs of climate change mitigation policies with and without linking top-down and bottom-up models. To our knowledge, this is the first study to illustrate the merits (or demerits) of linking top-down and bottom-up models for climate policy 
analysis. For this purpose, we measured the economy-wide costs of meeting China's pledges (or Nationally Determined Contributions, NDCs) under the Paris Agreement. Note that China has committed a goal of reducing its emission intensity (i.e., $\mathrm{CO} 2$ emissions per unit of GDP) by 60 to 65 percent below 2005 levels. It has also set a goal of increasing the share of nonfossil fuels to $20 \%$ of its total primary energy consumption by 2030 .

We first estimate the economic costs of meeting China's NDC using a CGE model alone. We use a carbon tax to meet the NDC. We then link the CGE model with the bottom-up TIMES model to produce a refined baseline which represents, through the TIMES model, the characteristics of hundreds of technologies in both energy supply and demand sides. ${ }^{3}$ We refer to this linkage of the CGE and TIMES models as a 'hybrid' model. The CGE model is run again based on this new baseline, and a new carbon tax is determined to meet the NDC. Corresponding economic implications are also measured. The study finds that the economic impacts measured by the stand-alone top-down model are much higher compared to those resulting from the hybrid model.

The paper is organized as follows. Section 2 briefly introduces the top-down CGE and bottom-up TIMES model. Also presented in this section is the methodology to link these two models. Section 3 describes the scenario developed to illustrate the difference in results without linkage (stand-alone mode) and with the linkage (hybrid mode). This is followed by the discussion of model results between these two modes. Section 5 presents the key conclusions of the study.

\section{Methodology}

In this section, we present the methodological approach used in the study. We start with the methodology to link the top-down CGE and the bottom-up TIMES models. This is followed by brief descriptions of the CGE and TIMES models.

We first ran the top-down CGE model and the bottom-up TIMES model independently and compared the variables which are common in both models. The common variables are energy demand projections (i.e., projection of coal, oil, natural gas, electricity). In the TIMES model, energy demand forecasts are mostly driven by main economic output (GDP). Moreover, there are many technology specific parameters, such as energy efficiency factors considered in

\footnotetext{
3 The details of the methodology to link the model are provided in the methodology section of this paper.
} 
both demand and supply sides in the TIMES model. Also important is the projection of energy prices, which are critical to producing an optimal mix of energy supply system in the TIMES model. The difference in energy demand is, therefore, obvious between the CGE model and the TIMES model when they are run independently.

\subsection{The Method to Link the CGE and TIMES Models}

The two models are then linked. The overall methodological framework for the linkage is illustrated in Figure 1. The detailed descriptions of the CGE model, TIMES model and the linkage methodology are provided in Appendix A, B and C, respectively.

Figure 1. Process of linking the CGE and TIMES models

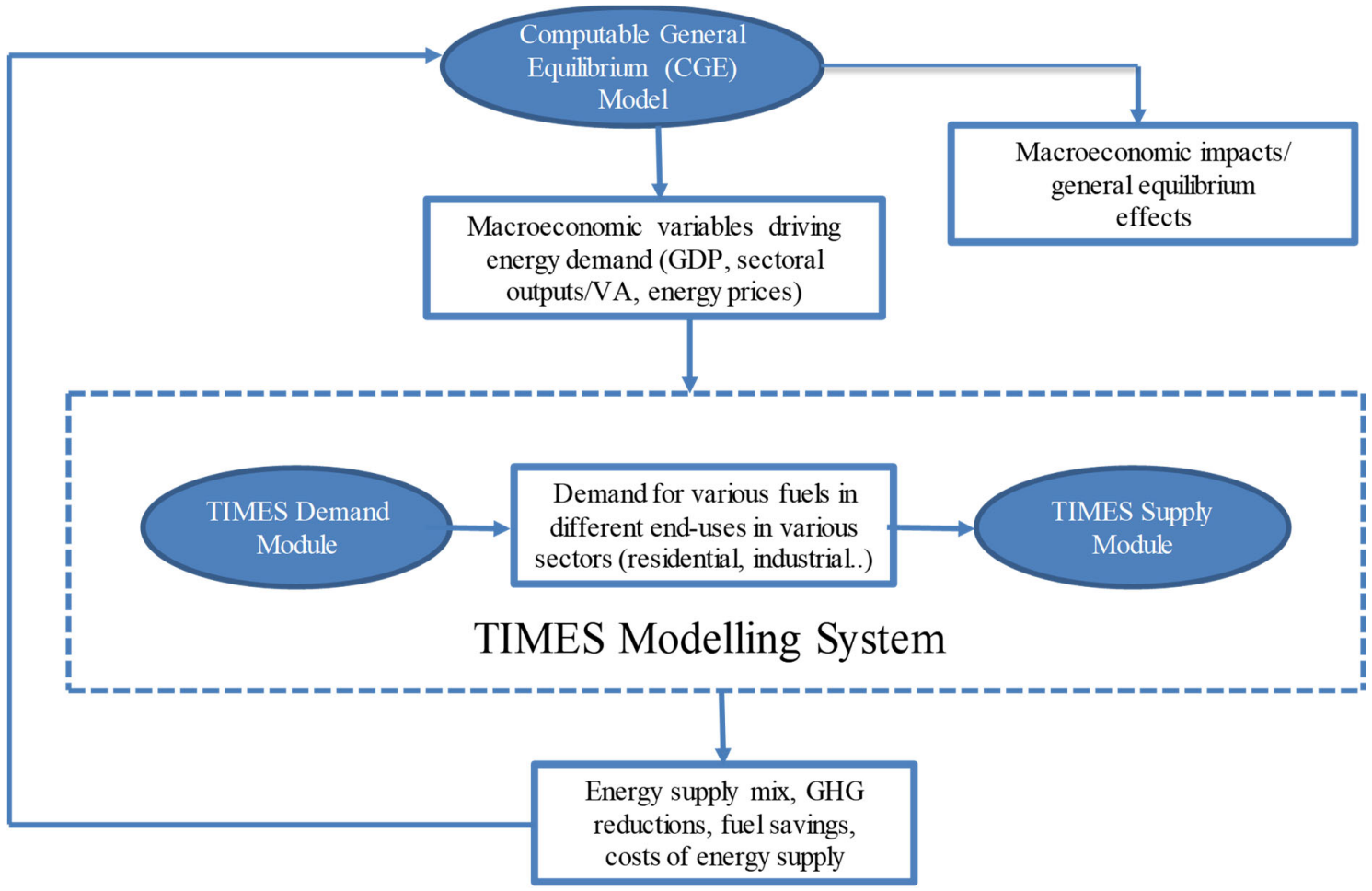

The CGE model is first run for a baseline scenario to project variables such as GDP and household income, sectoral output, and energy prices. These outputs of the CGE model are supplied to the TIMES model where they are used to project energy demand by end-use type (e.g., space heating and cooling, refrigeration, cooking, lighting, electrical motors, electronic appliances, process heating) in different sectors: households, commercial/service sectors, and industry (see Appendix $\mathrm{C}$ for the details). The projections incorporate various scenarios for energy efficiency improvements and their costs, depending on government incentives and other policies to improve energy efficiency. 
The end-use energy demand projected by the TIMES model and energy price indices provided by the CGE model are then used in TIMES to produce a mix of energy supply to meet the projected demands ensuring that the optimal energy supply mix represents the least cost scenario to deliver end-use energy services. Besides energy demands and prices the supply module of TIMES requires other input data including operational characteristics of energy supply technologies (e.g., power plant technologies, resource availability, such as solar irradiation in a given location for a solar power plant), and cost data (e.g., capital costs of photovoltaic cells, current fuel prices).

The projections of energy supply-mix produced by the TIMES model are supplied to the CGE model, where necessary parameters (e.g., share parameters, autonomous energy efficiency parameters) are adjusted in a way that the energy supply mix of the TIMES model is reflected in the CGE model. It implies that the growth rates of primary energy commodity (coal, oil, natural gas) in the CGE model are the same as in the TIMES model. The same should have been done for primary electricity. However, the CGE model has only one electricity commodity and does not explicitly represent the primary electricity. Therefore, growth rates of primary electricity in the TIMES model are not reflected in the CGE model. Moreover, new and renewable energy (solar, wind), which are explicit in the TIMES model, are embedded in the total electricity in the CGE model.

One would argue that why not disaggregate the electricity sector in the CGE model to various technologies in the same way several CGE models (e.g., Timilsina et al. 2018; Timilsina and Landis, 2014; Timilsina and Shretha, 2006) have done. However, the existing studies do not follow linking the CGE model with a bottom-up model. Instead, they refine their electricity sector modeling by disaggregating the electricity sector in their SAMs to various technologies (a kind of hard linking, as discussed earlier). Doing so partially brings some technological characteristics of electricity generation technologies into the CGE model, it still does not represent one of the main features of electricity sector operation, load dispatching. ${ }^{4}$ Moreover, even if we disaggregate the electricity sector to various technologies, it is not possible to disaggregate other energy/emission-intensive sectors, such as cement, chemicals, iron and steel. The detailed disaggregation is for hard linking of a top-down model with bottom-

\footnotetext{
${ }^{4}$ Load dispatching refers to operating of electricity generation plants to meet the demand in a given time based on their operating costs (mainly fuel costs), it is also called merit order dispatching in electricity economics literature.
} 
up technologies. We are here following a soft linking approach, therefore, believe that such disaggregation is not necessary. In fact, if we can disaggregate all sectors and represent them in the CGE model, the linkage of top-down and bottom-up models may not be necessary.

\subsection{Top-Down CGE Model}

The CGE model used in the study is a recursive dynamic model to analyze the economic effects of energy and environmental policies in China. It explicitly models the behavior of four economic agents: household, government, enterprise and the rest of the world (ROW). Production sectors are classified into 16 sectors, of which five are energy supply sectors (coal mining, oil and gas extraction, petroleum refinery, gas processing, and electric power generation). Please see Table 1 for the definitions of the sectors. A detailed description of the model is available in Appendix A.

Table 1. Definition of sectors/commodities in the CGE model

\begin{tabular}{l|l}
\hline Sector Name & \multicolumn{1}{c}{ Definition or coverage } \\
\hline AGRI & Agriculture, Forestry, Animal Husbandry and Fishery \\
\hline COAL & Mining and washing of coal \\
\hline OILNG & Extraction of petroleum and natural gas \\
\hline MINE & Mining and processing of metal and nonmetal \\
\hline FTPMF & Food, tobacco, textile, leather, fur, feather, timber, furniture, paper, printing \\
\hline PETRO & Processing of petroleum, coking, processing of nuclear fuel \\
\hline CHEMI & Manufacture of chemical products \\
\hline NMETA & Manufacture of non-metallic mineral products \\
\hline METAL & Smelting and processing of metals \\
\hline OTHMF & Other manufacture \\
\hline ELECT & Production and distribution of electric power and heat power \\
\hline GAS & Production and distribution of gas \\
\hline WATER & Production and distribution of tap water \\
\hline CONST & Construction \\
\hline TRANS & Transport, storage and postal services \\
\hline SERVI & Other services \\
\hline
\end{tabular}

Figure 2 illustrates the modeling of the behavior of each production sector. We use a sixtier nested constant elasticity of substitution (CES) combination function to represent a production sector. This multi-tier CES representation provides flexibility to the model by 
allowing different substitution possibilities across the tiers. Like in most CGE model formulations, we assume that the market follows perfect competition and the production process follows constant returns to scale.

Figure 2. Structure of production function in the CGE model

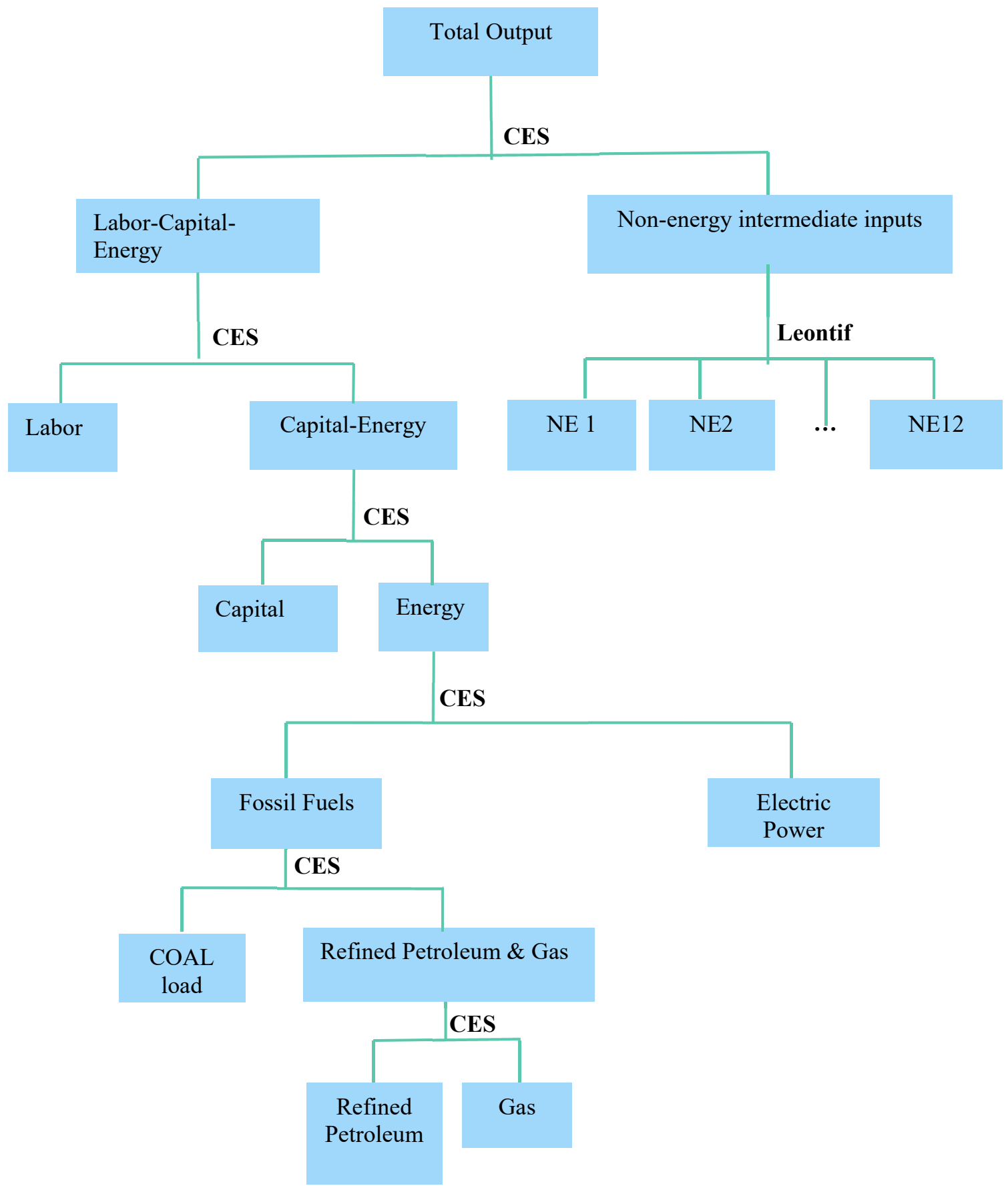


Domestic production and imports of a good/service are imperfect substitutes, popularly known as the Armington assumption. We use a CES function to combine them. A product is allocated to export and domestic markets following a constant elasticity of transformation (CET) function.

Enterprise income comes from capital returns and transfer payments from the government. Part of the after-tax enterprise income is transferred to the household, and the remainder is retained as profits from the enterprise. Households generate capital and labor incomes. Additionally, a household receives transfers from the government, the enterprise and from abroad. Household savings are determined based on marginal propensity to save and household expenditure is allocated to various goods and services through a Cobb-Douglas functional form. The government collects revenue through indirect taxes and import duties and goods/services, personal income tax on households and corporate income taxes on enterprises and transfer payments form other agents (households, enterprises and ROW). If a carbon tax is introduced, it is treated as an indirect tax on goods and services and carbon tax revenue goes to the government, which is recycled to the economy in different ways. Total government expenditure is kept fixed and allocated to the purchase of various goods and services at the same portion as in the baseline. Government savings are the difference between total government revenue and total government expenditure.

Like in a standard CGE model, total labor supply is equal to total labor demand at the national level where labor mobility is allowed across the sectors. The same is true for the capital account - total capital demand is equal to total capital demand and capital mobility is fixed across the sectors. Wage rates and capital prices (or user costs of capital) are different across the sectors. Similarly, the total supply of a good/service (imports plus domestic production) is equal to the total demand for that good/service (domestic consumption plus exports) Walrasian condition. The total investment is equal to total savings, which is the sum of household-, government-, firms- and foreign- savings (macroeconomic balance).

The model is made dynamic through population growth rate (i.e., labor supply growth rate) and investment. Total savings of the previous period (or year) is an investment of the current period (year). Demand for the total capital of the current period is determined by the previous period's capital stock plus depreciation and interest payment and new-added investment (which is the previous period's total savings). Total investment is allocated across sectors in proportion to each sector's share in the aggregate capital account, and these 
proportions are adjusted by the ratio of each sector's profit rate to the average profit rate for the whole economy. This is similar to the method used by Thurlow (2004), the details are discussed in the Appendix A. Also, Autonomous Energy Efficiency Improvement (AEEI) in the CGE model is considered in this study, and is assumed to be $1 \%$ per year following the common assumptions in CGE. Since the available social accounting matrix (SAM) is for 2012, our base year is 2012. If the model has to adopt a projected growth rate of GDP (e.g., projected by the government), it is done through adjustments in total factor productivities (TFPs).

The BAU scenario is constructed using assumptions on labor supply growth and projected real GDP growth, as shown in Table 2.

Table 2 The Labor supply growth rate and GDP growth rate from 2012 to 2030

\begin{tabular}{c|c|c}
\hline Year & Labor supply growth rate & Average annual GDP growth rate \\
\hline $2012-2015$ & $2.70 \%$ & $8.51 \%$ \\
\hline $2015-2020$ & $4.60 \%$ & $6.56 \%$ \\
\hline $2020-2025$ & 0 & $5.49 \%$ \\
\hline $2025-2030$ & 0 & $5.47 \%$ \\
\hline
\end{tabular}

Note: Values for 2012-2015 are actual or observed values. The projected GDP is set at a moderate level based on a review of relevant literature ${ }^{[0-8]}$. Labor supply growth rate are taken from China Statistic Year book 2017 and UNDESA ${ }^{[5]}$ with very small modification based on our understanding about labor quality development tendency of China in the future.

\subsection{Bottom-Up TIMES Model}

The bottom-up energy sector TIMES model is an optimization model. It is based on a reference energy system (RES) principle. An RES refers to an optimal system where useful energy demands by end-uses (e.g., light, heat, electric traction, motive power, etc.) in each sector (e.g., industrial, households) are met through various channels or networks, which transport energy commodities (coal, oil, gas, electricity) from domestic primary energy sources or imported primary or final energy sources. Figure 3 illustrates the RES on which the TIMES model used for this study is based. Various energy consumption technologies that produce final energy to useful energy (e.g., a boiler converts natural gas to heat, a light bulb converts electricity to light, an electrical motor converts electrical energy to mechanical energy) in the demand side whereas energy production or transformation technologies (e.g., electricity power 
plants to produce electricity from fuels) in the supply side. Energy transportation facilities (e.g., pipelines for oil and gas, transmission lines for electricity) carry energy commodities from production locations to demand centers.

Figure 3: RES Framework - the Foundation of a TIMES Model

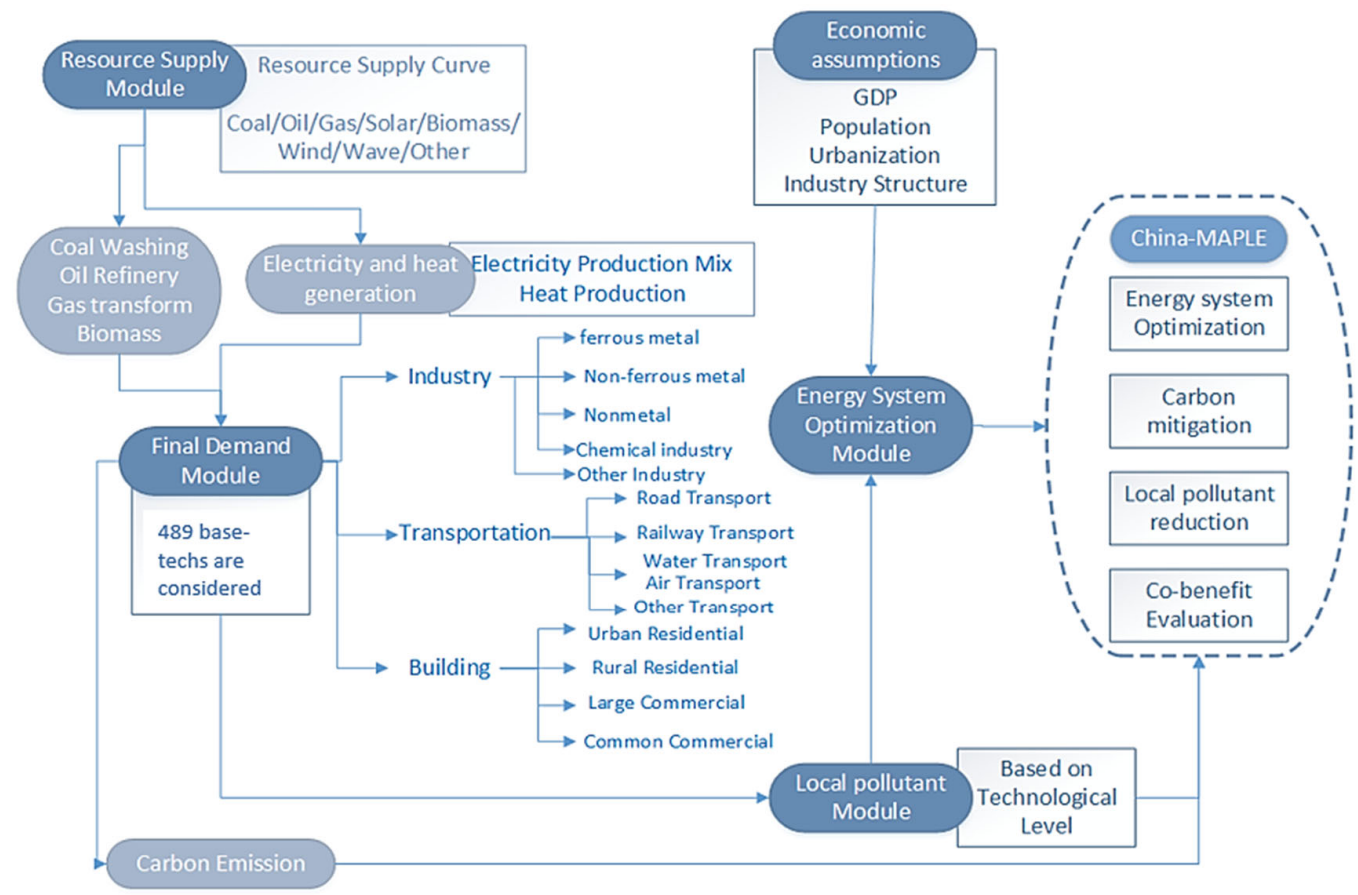

In the China TIMES model, ${ }^{5}$ there are five demand sectors: agriculture, industry, commercial, residential and transportation. Energy-intensive industry sectors are further divided into sub-sectors based on technology or fuels. For example, the chemical industry is first sub-divided into various sub-sectors based on product types, such as ammonia, ethylene, fertilizers, caustic soda etc. Each sub-sector is further divided based on the technology or fuel used. Altogether, the model considers 43 industrial sub-sectors and more than 400 technologies.

The building sector is divided into urban residential, rural residential, and commercial categories, and energy demand is further divided into space heating, cooling, water heating and cooking, lighting and electric appliances. Concerning different climate conditions and building design standards: four regions, Severe Cold (SC), Cold (C), Hot Summer Cold Winter (HSCW)

\footnotetext{
${ }^{5}$ There also exists a separate TIMES model for China (e.g., Chen, 2005; Chen et al. 2014). The structure of the existing TIMES models are also similar to the model used for this study.
} 
and Hot Summer Warm Winter (HSWW), are considered separately, based on the Standard of Climatic Regionalization for Architecture.

The transport sector is first divided into two categories: passenger and freight. The passenger transport is then divided into five types, and freight transport is divided into four types. Passenger services based on business LDVs owned by government bodies and companies are treated separately from private passenger services, as these do not generally compete with each other. Private passenger transport was disaggregated into four distinct inland passenger transport service types, based on geographical coverage and travel purposes: intercity, urban, rural, and business, and one international passenger service. Automobiles for passenger transportation are further divided by the type of fuel they use: gasoline driven, diesel driven, electricity-driven and hybrid. Freight transport encompasses two inland freight transportation services: domestic freight and two international freight transportation services. Within each type of transportation service, multiple subsectors representing available modal choices are created.

The TIMES model finds a mix of energy sources along with transformation/ transmission/transportation paths among the thousands of such possible mixes in such a way that the selected energy mix confirms that it is the least cost option to meet the given demand with available supply sources. While meeting projected end-use energy demand, the model satisfies all resources, technological, policy, and any other constraints specified. Thus, the model produces an optimal mix of energy supply sources (e.g., coal, oil, gas, LNG, hydro, solar, wind, biomass) to meet the end-use energy demand (e.g., space heating, space cooling, lighting, electric motors, motive power) in various sectors (i.e., residential, commercial/service, industrial and transport). While determining the optimal energy supply mix, the model simultaneously determines the cheapest path to transform/transmit/transport these energy commodities to energy end-uses.

End-use energy demands in TIMES are projected using driving factors such as economic growth, population growth, expected structural change in the economy, energy efficiency improvement in different technologies. Government plans and policies, such as building energy efficiency standards, industrial process energy efficiency standards, vehicle mileage standards are taken into consideration while projecting the demand. For example, the energy service demand projection in an industry sector (e.g., steel, cement, ammonia, aluminum, paper) is driven by its expected output, expected improvement in energy intensity 
of the output. At the beginning, the TIMES model uses energy drivers from various sources. When the TIMES model is linked with the CGE model, most of the drivers are taken from the CGE model outputs (e.g., the projection of output of an industry, price indices of the outputs). In the case of energy demand in buildings, a key driving variable again to be projected by the CGE model in the baseline is household income. This projection combined with other assumptions such as population growth, floor space per capita, energy requirement (e.g., lighting or heating energy requirement per unit of floor space) will determine energy demand. The demands for energy for transportation are determined through the projection of transportation services, which is driven by technological, economic and demographic factors.

The model does not include only existing technologies; it also considers future technologies, such as coal-fired power plants with carbon capture and storage (CCS) facilities, hydrogen fuel driven automobiles. The detailed representation of technology allows the substitution possibility between different types of technologies based on their production costs and other technological parameters. It also allows for the model to represent implementing government policies. For example, if the government plans to have a certain percentage of vehicles electricity driven or hybrid type in a given future year, the model can easily incorporate this policy.

\section{Scenarios for Illustrating Impact Assessment Improvement with the Linkage}

To illustrate, how the linkage of the top-down and the bottom-up models alters or improves the assessment of economic impacts of a climate change policy, we implement the methodological approach in the assessment of the economic impacts of meeting China's NDC. When the models are not linked, the CGE model is first run to produce the baseline. We iterate the CGE model with different carbon pricing until the solution reflects the NDC targets. The TIMES model can also be run independently. However, TIMES results are energy sector specific only. TIMES does not provide general equilibrium results (e.g., impacts on GDP, sectoral outputs, household income, international trade, etc.).

The CGE model and the TIMES model are then linked as discussed in the methodology section above. First, the TIMES and CGE models are run independently to produce corresponding baselines. The average annual growth rate (AARP) of GDP, the key economic driver for energy demand, is almost one percentage point higher in the CGE model as compared to that in the TIMES model. This is because the assumptions of future economic growth are different between these two models. The growth rates of energy commodities responsible for 
carbon emissions (i.e., coal, oil and natural gas) are different between the CGE and TIMES models for two reasons. First, the growth rate of their main economic driver, GDP, is different as shown above; and secondly, the TIMES model incorporates various technology-specific policies and assumptions in its energy demand forecast, whereas the CGE model is not capable of doing so as it cannot explicitly represent the detailed technologies.

In the first iteration to link the two models, we start using TIMES growth rates of fossil fuel demand in the CGE model. ${ }^{6}$ The growth rates of key economic drivers (GDP, sectoral outputs, electricity prices) projected by the CGE model are then used in the TIMES model. The results of the TIMES model, specifically the growth rates of primary energy commodities (coal, oil and natural gas) are sent back to the CGE model to run it again. We continue this process for a few rounds. Table 3 presents the growth rates of GDP and energy commodities between CGE and TIMES runs. In the beginning, the projected annual average growth rates of GDP for the 2015-2030 period were 5.8\% and 4.9\% in the CGE model and TIMES models, respectively. These numbers are different due to the difference in assumptions between the two models. Demand growth rates of fossil fuels are higher in the case of CGE models as compared to the TIMES model, as the TIMES model has incorporated some technology-specific policies, such as energy efficiency standards, that lower future energy demand, whereas the CGE model is not capable to incorporate detailed technology specific policies and standards. The difference in GDP is eliminated when the two models are linked so that the TIMES model uses economic drivers of energy demand (growth rates of GDP, sectoral outputs, energy prices) from the CGE model. After a few iterations, the gaps in growth rates of energy demand between the two models would be narrow.

Table 3. Annual Average Growth Rates of Key Variables while Linking the CGE and TIMES model to Produce a Converging Baseline

\begin{tabular}{|c|c|c|c|c|c|c|c|}
\hline \multicolumn{2}{|c|}{ GDP } & \multicolumn{2}{c|}{ Coal } & \multicolumn{2}{c|}{ Oil } & \multicolumn{2}{c|}{ Gas } \\
\hline CGE & TIMES & CGE & TIMES & CGE & TIMES & CGE & TIMES \\
\hline \multicolumn{6}{|c|}{ No Linkage: When CGE and TIMES model are run independently } \\
\hline $5.84 \%$ & $4.92 \%$ & $1.63 \%$ & $0.68 \%$ & $4.20 \%$ & $3.65 \%$ & $6.87 \%$ & $3.21 \%$ \\
\hline
\end{tabular}

${ }^{6}$ We could have started by using the GDP and energy consumption growth of the CGE model in the TIMES model, however, doing so we found more iterations are needed to get convergence of the results of the two models. 


\begin{tabular}{|c|c|c|c|c|c|c|c|}
\hline \multicolumn{8}{|c|}{$\begin{array}{l}\text { First iteration run: TIMES growth rates of fossil fuels from no-linke } \\
\text { resulting outputs of CGE (growth rates of GDP, sectoral output, energ } \\
\text { TIMES model (TIMES } \rightarrow \text { CGE } \rightarrow \text { TIMES) }\end{array}$} \\
\hline $5.85 \%$ & $5.85 \%$ & $1.39 \%$ & $0.56 \%$ & $3.45 \%$ & $1.72 \%$ & $3.44 \%$ & $3.41 \%$ \\
\hline \multicolumn{8}{|c|}{$\begin{array}{l}\text { Second iteration run: TIMES growth rates of fossil fuels from the } 1^{\text {st }} \text { iteration and GDP growth } \\
\text { rate of CGE from the } 1^{\text {st }} \text { iteration are fed into CGE and resulting outputs of CGE (growth rates of } \\
\text { GDP, sectoral output, energy prices) are used in the TIMES model (TIMES } \rightarrow \text { CGE } \rightarrow \text { TIMES) }\end{array}$} \\
\hline $5.78 \%$ & $5.78 \%$ & $0.10 \%$ & $-0.62 \%$ & $3.02 \%$ & $2.50 \%$ & $2.34 \%$ & $2.50 \%$ \\
\hline
\end{tabular}

\section{Results from Model Simulations}

The economic impacts of implementation of NDC assessed through a CGE model stand alone and the CGE model linked with the TIMES model (hybrid mode) are presented in Figure 4. Intuitively, meeting China's NDC would cost the economy as compared to the situation when the NDC is not met (or baseline scenario). However, the magnitudes of the impacts are significantly sensitive to the model or methodology used for their estimation. Economic impacts are found much higher when they are estimated using a stand-alone CGE model as compared to the that made by the CGE model after it is linked with the TIMES model. Impacts on key economic variables are $50 \%$ to $80 \%$ lower when they are measured linking the CGE model with the TIMES model than when they are measured using the CGE model without linking. For example, the GDP impact estimated through the linked model is $77 \%$ smaller than that measured with the not-linked CGE model.

An obvious question would be why are CGE stand-alone model estimates higher compared to those measured through the linked CGE model? We checked if this happened due to the correction of the baseline through the linkage of the CGE model with the TIMES. If the economic indicators (i.e., GDP, sectoral outputs, demand for goods/services, imports, exports, etc.) are bigger after the correction of the baseline through the linkage, the corresponding impacts of NDC implementation (i.e., the change in their values under NDC from that in the corrected baseline) would be smaller. This is because these economic indicators are compared with a higher base then they were earlier (i.e., baseline before the linkage). This is true for some indicators, such as government accounts (i.e., government consumption, government savings and also the investment as government savings is part of total investment); this is not the case for other variables. 
Since the initial (before linking) growth rates of fossil fuels and $\mathrm{CO}_{2}$ emissions under the TIMES model are much lower as compared to those in the CGE model, it causes reductions in baseline emissions from the hybrid model (after linkage). The main reason for the higher baseline emissions under the top-down model is that it often excludes existing policies specific to sectors, sub-sectors and technologies not explicitly available in their database, social accounting matrix (SAM) or input-output (I-O) tables.

Figure 4: Economic impacts of meeting China's NDC under stand-alone and hybrid modes of modeling 


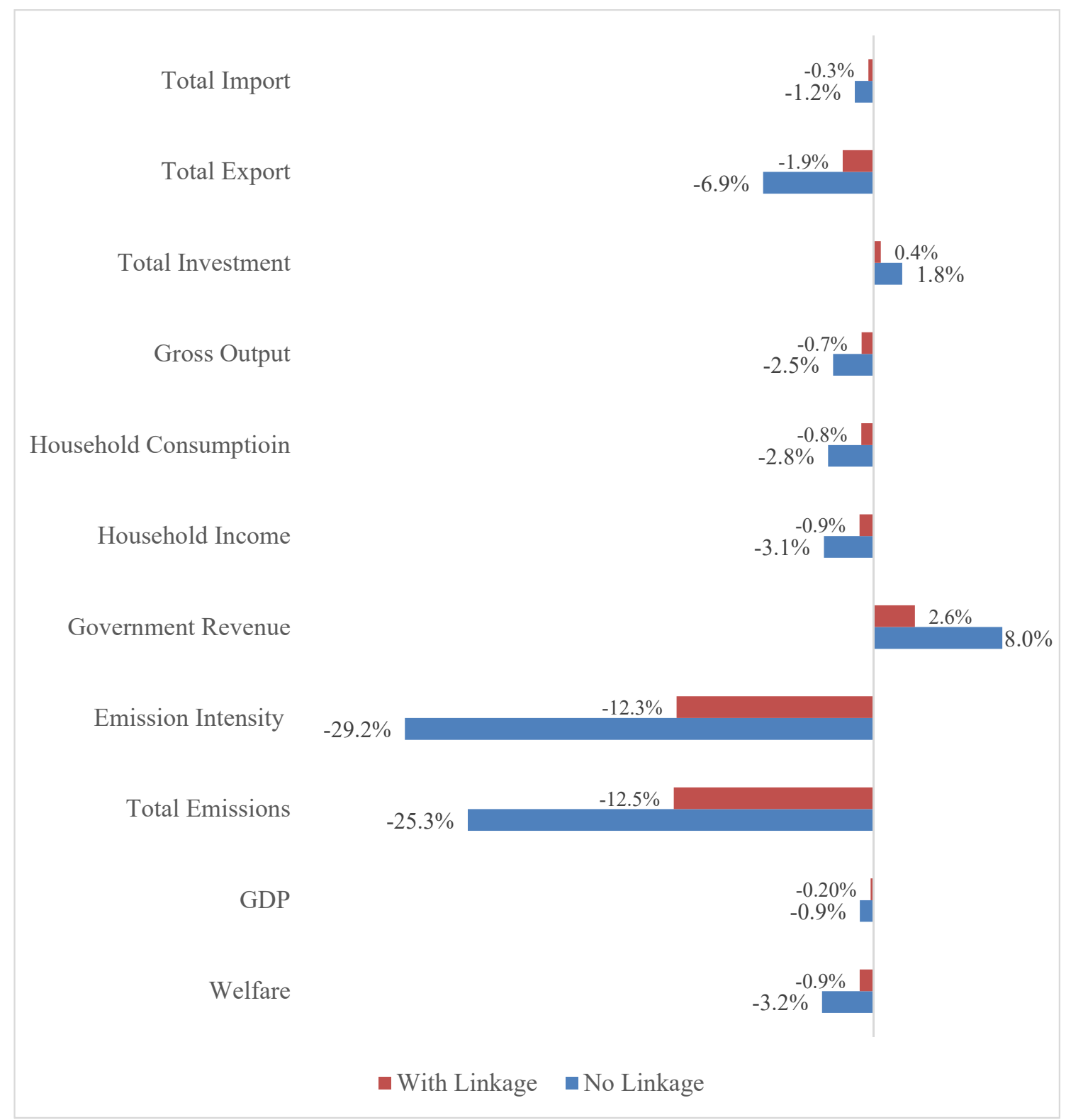

The carbon tax required to meet the NDC is $¥ 372 / \mathrm{tCO}_{2}$ when the models are not linked; it drops by $70 \%$ to $¥ 110 / \mathrm{tCO}_{2}$. As the rate of carbon tax decreases, its impacts on the economy also decrease no matter the direction of the impacts. The drop in the carbon tax rate can be explained by the marginal cost curve of $\mathrm{CO}_{2}$ emission reduction in China presented in Figure 5. This curve is plotted by running the CGE models at various carbon tax rates, 100, 200, 400, 500 yuan per ton of $\mathrm{CO}_{2}$ against the corresponding percentage reduction of $\mathrm{CO}_{2}$ emissions from the baseline in 2030. The shape of the marginal abatement curve indicates that the shadow price of carbon would be around $¥ 100 / \mathrm{tCO}_{2}$ for about $10 \%$ reduction of $\mathrm{CO} 2$ from the baseline. If 
the percentage reduction is increased to $30 \%$, the carbon price increases to $¥ 500 / \mathrm{tCO}_{2}$, this precisely explains the drop in carbon prices and corresponding economic impacts under the linked case from the stand-alone CGE case. Under the stand-alone CGE case, the required reduction of $\mathrm{CO}_{2}$ from the baseline in 2030 to meet the $\mathrm{NDC}$ was $25 \%$, it decreases to $12 \%$ under the linked case (see Figure 4). This happened because of a $14 \%$ drop of baseline $\mathrm{CO}_{2}$ emissions in 2030 under the linked case from the stand-alone CGE case. The linkage of the two models helped correct the growth of fossil fuel demand, mainly through the substitution of fossil fuels with renewable energy sources and also through energy efficiency improvements in demand-side energy conversion and utilization technologies.

Figure 5. The marginal cost of $\mathrm{CO} 2$ reduction in China

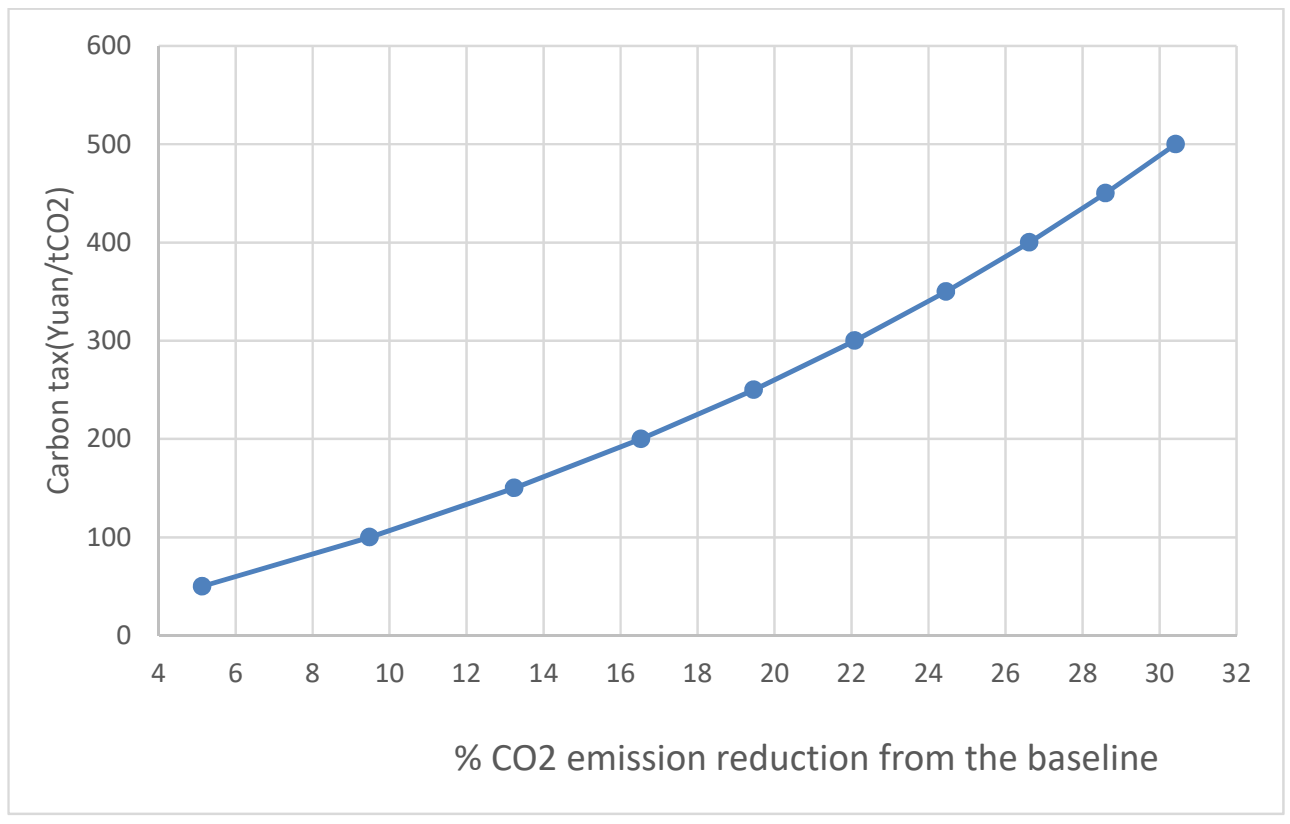

Tables 4 and 5 present sectoral and commodity impacts. As expected, energy sectors (e.g., coal, oil, petroleum products, gas, electricity) and energy-intensive sectors (e.g., metals, minerals and non-metals, chemicals) would face higher percentage reductions of $\mathrm{CO}_{2}$ emissions and also higher drops of sectoral outputs (see Table 4). Like in the case of the results presented in Figure 4, the sectoral impacts are significantly smaller under the linked case as compared to the not-linked case for the same reason explained above. 
Table 4. Impacts on $\mathrm{CO}_{2}$ emissions and economic outputs at the sectoral level in 2030 (\% change from the baseline)

\begin{tabular}{|c|c|c|c|c|}
\hline \multirow[t]{2}{*}{ Sector } & \multicolumn{2}{|c|}{$\mathrm{CO}_{2}$ emissions } & \multicolumn{2}{|c|}{ Sectoral output } \\
\hline & $\begin{array}{c}\text { Not-Linked } \\
\text { Case }\end{array}$ & $\begin{array}{c}\text { Linked } \\
\text { Case }\end{array}$ & $\begin{array}{c}\text { Not-Linked } \\
\text { Case }\end{array}$ & $\begin{array}{c}\text { Linked } \\
\text { Case }\end{array}$ \\
\hline Agriculture, Forestry, Animal Husbandry and Fishery & -11.4 & -4.1 & -0.6 & -0.1 \\
\hline Extraction of petroleum and natural gas & -27.8 & -10.9 & -12.7 & -4.4 \\
\hline Mining and processing of metal and nonmetal & -22.2 & -8.6 & -5.3 & -1.6 \\
\hline Food, tobacco, textile, leather, fur, feather, timber, furniture, paper, printing & -28.5 & -11.9 & -1.2 & -0.2 \\
\hline Manufacture of chemical products & -25.4 & -10.2 & -5.7 & -1.8 \\
\hline Manufacture of non-metallic mineral products & -27.6 & -11.9 & -3.4 & -1.0 \\
\hline Smelting and processing of metals & -26.8 & -11.2 & -4.8 & -1.4 \\
\hline Other manufacture & -25.7 & -10.2 & -2.4 & -0.7 \\
\hline Production and distribution of electric power and heat power & -34.2 & -14.8 & -18.9 & -7.0 \\
\hline Production and distribution of gas & -39.9 & -15.9 & -19.2 & -5.2 \\
\hline Production and distribution of tap water & -23.6 & -9.4 & -2.9 & -0.9 \\
\hline Construction & -12.2 & -4.6 & 0.7 & 0.1 \\
\hline Other services & -19.3 & -6.4 & 0.7 & 0.2 \\
\hline
\end{tabular}


Table 5. Impacts on household consumption, imports and exports of goods and services in 2030 (\% change from the baseline)

\begin{tabular}{|c|c|c|c|c|c|c|}
\hline \multirow[t]{2}{*}{ Sector } & \multicolumn{2}{|c|}{ Household consumption } & \multicolumn{2}{|c|}{ Imports } & \multicolumn{2}{|c|}{ Exports } \\
\hline & $\begin{array}{l}\text { Not-Linked } \\
\text { Case }\end{array}$ & $\begin{array}{l}\text { Linked } \\
\text { Case }\end{array}$ & $\begin{array}{l}\text { Not-Linked } \\
\text { Case }\end{array}$ & $\begin{array}{l}\text { Linked } \\
\text { Case }\end{array}$ & $\begin{array}{l}\text { Not-Linked } \\
\text { Case }\end{array}$ & $\begin{array}{l}\text { Linked } \\
\text { Case }\end{array}$ \\
\hline $\begin{array}{l}\text { Agriculture, Forestry, Animal Husbandry } \\
\text { and Fishery }\end{array}$ & -1.0 & -0.2 & -5.3 & -1.5 & 5.6 & 1.7 \\
\hline Coal & -2.2 & -0.5 & -9.9 & -5.9 & -59.0 & -26.8 \\
\hline Oil and natural gas & -7.7 & -2.6 & -12.4 & -4.2 & -13.2 & -4.7 \\
\hline Metal and nonmetal & -6.0 & -1.9 & -2.8 & -0.6 & -9.5 & -3.3 \\
\hline $\begin{array}{l}\text { Food, tobacco, textile, leather, fur, } \\
\text { feather, timber, furniture, paper, printing }\end{array}$ & -8.7 & -2.6 & -4.2 & -1.4 & 3.7 & 1.7 \\
\hline Petroleum, coke, nuclear fuel & -1.0 & -0.2 & -3.0 & -1.0 & -28.6 & -11.1 \\
\hline Chemical products & -2.2 & -0.5 & 6.5 & 2.2 & -15.9 & -5.5 \\
\hline Non-metallic mineral products & -7.7 & -2.6 & 29.7 & 8.1 & -25.2 & -8.5 \\
\hline Metals & - & - & 10.2 & 2.7 & -21.5 & -6.7 \\
\hline Other manufacturing goods & -3.7 & -1.0 & 0.3 & 0.1 & -5.3 & -1.6 \\
\hline Electricity and heat & -20.6 & -7.3 & 44.8 & 12.8 & -39.8 & -15.8 \\
\hline Processed gas & -11.3 & -2.7 & - & - & - & - \\
\hline Tap water & -3.2 & -1.0 & - & - & - & - \\
\hline Construction materials & - & - & 2.6 & 0.7 & -3.0 & -1.1 \\
\hline Transport, storage and postal services & -3.9 & -1.0 & -0.4 & -0.3 & -4.6 & -0.9 \\
\hline Other services & -1.5 & -0.4 & -2.8 & -0.8 & 5.9 & 1.7 \\
\hline
\end{tabular}


We also review the results of existing studies to gain confidence in our key finding. While no similar study is available in the literature, the comparison of various models periodically made by the Standford University based energy modeling forum (EMF) could be useful. EMF includes different types of models, most of them are global macroeconomic models (mostly general equilibrium type) and some models it uses are energy system models, like the bottomup TIMES model we use here in this study. ${ }^{7}$ Models, such as MESSAGE and DNE-21, GETLFL presented in Edenhoffer et al. (2006), and POLES and MESSAGE included in De la Chesnaye and Weyant (2006) are energy system models. While comparing the economic costs of stabilizing global GHG concentration (stabilizing the forcing at 4.5 Watt per square meter by the year 2150), De la Chesnaye and Weyant (2006) report that the percentage reduction of $\mathrm{CO}_{2}$ emissions and corresponding carbon tax estimated by the energy system models are much smaller as compared to that estimated by CGE models. For example, to meet the stabilization scenario as specified in De la Chesnaye and Weyant (2006), global CGE models like AIM, EPPA, SGM estimate about US\$500/tCO 2 carbon tax in the year 2050, whereas MESSAGE's estimate is about US\$200/tCO 2 . While comparing the economic impacts estimated by different models to achieve a climate stabilization scenario, Edenhoffer et al. (2006) report that the percentage changes in gross world products from the baseline estimated by energy system models (DEN-21, GET-LFL) are 60-70\% lower than that estimated by CGE models IAM and IMACLIM-R. These results from the literature also strengthen the findings of our study.

\section{Conclusions}

This study examines how the overall economic impacts of climate change mitigation policies (here meeting China's pledges under the Paris Agreement or NDCs) differ when information on detailed technologies is incorporated in the analytical tool. A top-down CGE model, which is often used to measure economic impacts of climate change mitigation policies, is linked to an energy-sector bottom-up engineering model, which is capable of representing detailed technologies in the various stages of the energy supply chain (production, transformation, transportation and utilization). The study finds that the economic impacts measured by the stand-alone top-down model are almost three times as high as those resulting

\footnotetext{
7 These energy system models either have their own simplistic macro module or use other macroeconomic models to estimate economic impacts of climate change policies they simulate.
} 
from the linkage of the top-down model with the bottom-up model. The carbon tax required to meet the NDC under the linkage case is found to be less than one-third of that in the absence of the linkage. This explains the reason why the economic impacts under the former case are lower as compared to that of the latter. The conclusion here is that top-down CGE models tend to overestimate the impacts of climate change policies because they are unable to reflect detailed technology specific energy standards and policies already in place or planned for the near future.

Although the linked modeling approach tends to correct the likely overestimates of the economic impacts of a climate change policy, the results should be interpreted with care, as the initial projection of the energy-supply mix produced by the bottom-up model might have influenced by modeler's optimistic assumptions on energy efficiency improvements. If so, the baseline GHG emissions get underestimated, thereby resulting in a smaller gap between the target and baseline emissions, and the required carbon tax to achieve the mitigation target. It is, therefore, the development of the baseline (implicit assumptions on the driving variables of the baselines) that is critical in both models. The linkage of the two models, however, dampens the variations in the baselines from the two models, thereby helping to estimate more reliable economic and environmental impacts of climate change mitigation policy as compared to that estimated by the stand-alone models.

\section{References}

Böhringer, C., and T. Rutherford (2008). “Combining bottom-up and top-down.” Energy Economics, 30 (2), pp. 574-596.

Böhringer, C., and T. Rutherford (2009). "Integrated Assessment of Energy Policies: Decomposing Top-down and Bottom-up.” Journal of Economic Dynamics and Control, 33, pp. 1648-1661.

Bukowski, M. and Kowal, P. (2010). "Large scale, multi-sector DSGE model as a climate policy assessment tool.” Working paper. Institute for Structural Research, Poland.

Chen, Wenying, Xiang Yin, and Ding Ma. 2014. “A Bottom-up Analysis of China's Iron and Steel Industrial Energy Consumption and CO2 Emissions.” Applied Energy 136: 1174 83.

Chen, Wenying. 2005. "The costs of mitigating carbon emissions in China: findings from China MARKAL-MACRO modeling” Energy Policy, 33:885-896. 
Dai, H., T. Masui, Y. Matsuoka and S. Fujimori (2011). Assessment of China's climate commitment and non-fossil energy plan towards 2020 using hybrid AIM/CGE model. Energy Policy, Vol. 39, No. 5. pp. 2875-2887.

Dai, H. and P. Mischke (2014). Future energy consumption and emissions in East-, Centraland, West-China: Insights from soft-linking two global models. Energy Procedia 61: $2584-2587$.

Dai, H., P. Mischke, X. Xie, Y. Xie and T. Masui (2016). Closing the gap? Top-down versus bottom-up projections of China's regional energy use and CO2 emissions, Applied Energy, Volume 162, Pages 1355-1373.

De la Chesnaye, F. and J.P. Weyant (2006). Multi-Greenhouse Gas Mitigation and Climate Policy. The Energy Journal, Special Issue.

Drouet, L., Haurie, A., Labriet, M., Thalmann, P., Vielle, M., Vigier, L. (2005). “A coupled bottom-up/top-down model for GHG abatement scenarios in the Swiss housing sector.” In: Loulou, R., Waaub, J. P., Saccour, G. (Eds.), Energy and Environment, Cambridge, pp. 27-62.

Edenhofer, O., C. Carraro, J. Kohler and M. Grubb (Ed.) (2006). Endogenous Technological Change and the Economics of Atmospheric Stabilization. The Energy Journal, Special Issue.

National Bureau of Statistics (NBS). China input-output tables 2012./http://data.stats.gov.cn/informal.htm?u=/files/HTML/quick search/trcc/trcc01.html \& h=740). (in Chinese).

OECD. 2012. Looking to 2060: Long-term global growth prospects. OECD economic policy papers. Paris: OECD Publishing.

Qing-Hua Bi, Ying Fan, Sheng-Hua Cai and Yan Xia. 2013. Scenarios Analysis of China's Primary Energy Demand: Based on CDECGE Model. China Population Resource and Environment, 23(1): 41-48. (in Chinese).

Scahafer, A. and Jacoby, H. (2006). "Experiments with a hybrid CGE-Markal model." Energy Journal, pp.171-178 (special issue).

Thurlow, J. (2004). A Dynamic Computable General Equilibrium (CGE) Model for South Africa: Extending the Static IFPRI Model. TIPS Working Paper Series (WP1-2004), $53-55$. 
Timilsina, Govinda R. and Erika Jorgensen (2018). The Economics of Greening Romania's Energy Supply System. Mitigation and Adaptation Strategies for Global Change, Vol. 23, pp.123-144.

Timilsina, G. R. and R.M. Shrestha, (2006), General Equilibrium Effects of a Supply Side GHG Mitigation Option under the Clean Development Mechanism, Journal of Environmental Management, Vol. 80, pp. 327-341.

Timilsina, G.R. and F. Landis (2014). Economics of Transiting to Renewable Energy in Morocco: A General Equilibrium Analysis, World Bank Policy Research Working Paper, WPS 6940, World bank, Washington, DC.

UNDESA. World population prospects. 2015. New York: Population Division, Department of Economic and Social Affairs, United Nations; 2015.

United Nations Framework Convention on Climate Change (UNFCCC) (2015). Report of the Conference of the Parties on its nineteenth session, held in Paris from 30 November to 11 December 2015, Addendum Part Two: Action taken by the Conference of the Parties at its twenty-one session, UNFCCC, Bonn, Germany.

United Nations Framework Convention on Climate Change (UNFCCC) (2016). The aggregate effect of the intended nationally determined contributions: an update, Synthesis report by the secretariat. http://unfccc.int/resource/docs/2016/cop22/eng/02.pdf

Weyant, J.P. (Ed.) (1999). The Costs of the Kyoto Protocol: A Multi-Model Evaluation. The Energy Journal, Special Issue.

Wing, I. S., 2008. The synthesis of bottom-up and top-down approaches to climate policy modeling: electric power technology detail in a social accounting framework. Energy Economics, 30(2), 547-573.

World Bank (2014). FYR Macedonia: Green Growth Country Assessment. World Bank, Washington, DC.

World Bank (2016). Romania: Green Growth Country Assessment. World Bank, Washington, DC. 


\section{Appendix A: Detailed Description of the CGE Model}

\section{A1. Model Structure}

Naming rules for variables:

(1) Endogenous variables are named as uppercase letters, and exogenous variables are named as uppercase letters with a cross line above; (2) Variables are generally named as their recognized prefix, as $\mathrm{Q}$ is quantity, $\mathrm{P}$ is commodity price, $\mathrm{W}$ is factor price, $\mathrm{Y}$ is income, $\mathrm{E}$ is expenditure; (3) The initial value of all variables in the business-as-usual scenario are used as parameters and are named as original names with 0 added behind, while other parameters are named as lowercase letters.

\section{Definition of sets:}

$\mathrm{I}, \mathrm{J}=\{$ production sectors or commodities $\}$;

$\mathrm{F}=\{$ factors, including capital and labor $\}$;

$\mathrm{E}(\subset \mathrm{I}, \mathrm{J})=\{$ energy sector or commodity $\}$;

$\mathrm{NE}(\subset \mathrm{I}, \mathrm{J})=\{$ non-energy sector or commodity $\}$;

\section{A1.1 Production module}

Constant elasticity of substitution (CES) functions with six levels of nesting are used to characterize production behaviors in this model: the first level is the aggregation of production factors and non-energy intermediate inputs; the second level includes the aggregation of labor and capital-energy and that of each non-energy intermediate input; the third level is the aggregation of capital and energy; the fourth level is the aggregation of electric power and fossil fuels; the fifth level is the aggregation of coal and the composite inputs of refined petroleum and gas; the sixth level is the aggregation of refined petroleum and gas.

The structure of the production function is given in Figure 2 in the main text of the paper.

\section{A1.1.1 The first level of the CES function of total productivity}

The aggregation of value-added and intermediate input:

$$
Q A_{i}=\alpha_{i}^{A} \cdot\left[\delta_{i}^{A} \cdot Q V A_{i}^{\rho_{i}^{A}}+\left(1-\delta_{i}^{A}\right) \cdot Q I N T A_{i}^{\rho_{i}^{A}}\right]^{1 / \rho_{i}^{A}}
$$

where $Q A_{i}$ is the total production of sector i, $Q V A_{i}$ and $Q I N T A_{i}$ are the input of value-added and intermediate input in sector i respectively, $\delta_{i}^{A}$ and $\alpha_{i}^{A}$ are the share parameter and efficiency parameter; $\rho_{i}^{A}$ is the substitution elasticity parameter between value-added and intermediate input, and $\sigma_{\mathrm{i}}^{A}=1 /\left(1-\rho_{i}^{A}\right), \sigma_{i, r}^{A}$ is the substitution elasticity between value-added and intermediate input. 
Optimal factor input under total production:

$$
\frac{P V A_{i}}{P I N T A_{i}}=\frac{\delta_{i}^{A}}{1-\delta_{i}^{A}} \cdot\left(\frac{Q I N T A_{i}}{Q V A_{i}}\right)^{1-\rho_{\mathrm{i}}^{A}}
$$

where $P V A_{i}$ and $P I N T A_{i}$ are the price of value-added and intermediate input in sector $\mathrm{i}$ in region $r$ respectively.

Relationship of price of total output:

$$
P A_{i} \cdot Q A_{i}=P V A_{i} \cdot Q V A_{i}+P I N T A_{i} \cdot Q I N T A_{i}
$$

where $P A_{i}$ is the producer price of sector $\mathrm{i}$.

\section{A1.1.2 Intermediate input function}

The quantity of intermediate input of non-energy commodity:

$$
\operatorname{QINT}_{j, i}=i c a_{j, i} \cdot \operatorname{QINTA}_{i} \quad j \in N E
$$

The price of intermediate input:

$$
\operatorname{PINTA}_{i}=\sum_{j} i c a_{j, i} \cdot P Q_{i} \quad j \in N E
$$

where $Q I N T_{j, i}$ is the quantity of the input of non-energy commodity $\mathrm{j}$ as intermediate input of sector $\mathrm{i}, i c a_{j, i}$ is the intermediate input coefficient, denoting the proportion of the input of nonenergy commodity $\mathrm{j}$ in the total intermediate input of sector $\mathrm{i}$.

\section{A1.1.3 The second level of the CES function of value-added}

The aggregation of labor and capital-energy:

$$
Q V A_{i}=\alpha_{i}^{v a} \cdot\left[\delta_{i}^{v a} \cdot Q L D_{i}^{\rho_{i}^{v a}}+\left(1-\delta_{i}^{v a}\right) \cdot Q K E D_{i}^{\rho_{i}^{v a}}\right]^{1 / \rho_{i}^{v a}}
$$

Where $Q L D_{i}$ and $Q K E D_{i}$ are the input of labor and capital-energy in sector i respectively, $\delta_{i}^{v a}$ and $\alpha_{i}^{v a}$ are the share parameter and efficiency parameter; $\rho_{i}^{v a}$ is the substitution elasticity parameter between labor and capital-energy, and $\sigma_{i}^{v a}=1 /\left(1-\rho_{i}^{v a}\right), \sigma_{i}^{v a}$ is the substitution elasticity between labor and capital-energy.

Optimal factor input of value-added: 
$\frac{W L_{i}}{P K E_{i}}=\frac{\delta_{i}^{v a}}{1-\delta_{i}^{v a}} \cdot\left(\frac{Q K E D_{i}}{Q L D_{i}}\right)^{1-\rho_{i}^{v a}}$

Relationship of price of the input of value-added:

$P V A_{i} \cdot Q V A_{i}=W L \cdot Q L D_{i}+P K E_{i} \cdot Q K E D_{i}$

where $W L_{i}$ and $P K E_{i}$ are the price of the input of labor and capital-energy in sector $\mathrm{i}$ respectively.

\section{A1.1.4 The third level of the CES function of capital-energy}

The aggregation of capital and energy:

$$
Q K E D_{i}=\alpha_{i}^{k e} \cdot\left[\delta_{i}^{k e} \cdot Q K D_{i}^{\rho_{i}^{k e}}+\left(1-\delta_{i}^{k e}\right) \cdot Q E D_{i}^{\rho_{i}^{k e}}\right]^{1 / \rho_{i}^{k e}}
$$

where $Q K D_{i}$ and $Q E D_{i}$ are the input of capital and energy in sector i respectively, $\delta_{i}^{k e}$ and $\alpha_{i}^{k e}$ are the share parameter and efficiency parameter; $\rho_{i}^{k e}$ is the substitution elasticity parameter between the input of capital and energy, and $\sigma_{i}^{k e}=1 /\left(1-\rho_{i}^{k e}\right), \sigma_{i}^{k e}$ is the substitution elasticity between the input of capital and energy.

Optimal factor input:

$$
\frac{W K_{i}}{P E C_{i}}=\frac{\delta_{i}^{k e}}{1-\delta_{i}^{k e}} \cdot\left(\frac{Q E D_{i}}{Q K D_{i}}\right)^{1-\rho_{i}^{k e}}
$$

where $W K_{i}$ and $P E C_{i}$ are the price of the input of capital and energy in sector i respectively.

Relationship of price of the input of capital and energy:

$$
P K E_{\mathrm{i}} \cdot Q K E D_{\mathrm{i}}=W K \cdot Q K D_{\mathrm{i}}+P E C_{\mathrm{i}} \cdot Q E D_{\mathrm{i}}
$$

\section{A1.1.5 The fourth level of the CES function of the aggregation of energy}

The aggregation of fossil fuels and electric power:

$$
Q E D_{i}=\alpha_{i}^{e c} \cdot\left[\delta_{i}^{e c} \cdot Q E F_{i}^{\rho_{i}^{e c}}+\left(1-\delta_{i}^{e c}\right) \cdot Q E E_{i}^{\rho_{i}^{e c}}\right]^{1 / \rho_{i}^{e c}}
$$

where $Q E F_{i}$ and $Q E E_{i}$ are the input of fossil fuels and electric power in sector i respectively, $\delta_{i}^{e c}$ and $\alpha_{i}^{e c}$ are the share parameter and efficiency parameter; $\rho_{i}^{e c}$ is the substitution elasticity parameter between the input of fossil fuels and electric power, and $\sigma_{i}^{e c}=1 /\left(1-\rho_{i}^{e c}\right), \sigma_{i}^{e c}$ is the substitution elasticity between the input of fossil fuels and electric power. 
Optimal factor input of the aggregation of energy:

$$
\frac{P E F_{i}}{P E E_{i}}=\frac{\delta_{i}^{e c}}{1-\delta_{i}^{e c}} \cdot\left(\frac{Q E E_{i}}{Q E F_{i}}\right)^{1-\rho_{i}^{e c}}
$$

where $P E F_{i}$ and $P E E_{i}$ are the price of the input of fossil fuels and electric power in sector $\mathrm{i}$ respectively.

Price relationship of the input of the aggregation of energy:

$$
P E C_{i} \cdot Q E D_{i}=P E F_{i} \cdot Q E F_{i}+P E E_{i} \cdot Q E E_{i}
$$

\section{A1.1.6 The fifth level of the CES function of the aggregation of fossil fuels}

The aggregation of coal and refined petroleum-gas:

$$
Q E F_{i}=\alpha_{i}^{e f} \times\left[\delta_{i}^{e f} \times Q E \operatorname{coal}_{i}^{\rho_{i}^{e f}}+\left(1-\delta_{i}^{e f}\right) \times \operatorname{QEoilgas}_{i}^{\rho_{i}^{e f}}\right]^{1 / \rho_{i}^{e f}}
$$

where QEcoal $_{i}$ and QEoilgas $_{i}$ are the input of coal and refined petroleum-gas in sector i in region $\mathrm{r}$ respectively, $\delta_{i}^{e f}$ and $\alpha_{i}^{e f}$ are the share parameter and efficiency parameter; $\rho_{i}^{e f}$ is the substitution elasticity parameter between the input of coal and refined petroleum-gas, and $\sigma_{i}^{e f}=1 /\left(1-\rho_{i}^{e f}\right), \sigma_{i}^{e f}$ is the substitution elasticity between the input of coal and refined petroleum-gas.

First order condition of optimal factor input:

$$
\frac{\text { PEcoal }_{i}}{\text { PEoilgas }_{i}}=\frac{\delta_{i}^{e f}}{\left(1-\delta_{i}^{e f}\right)} \cdot\left(\frac{\text { QEoilgas }_{i}}{\text { QEcoal }}\right)^{1-\rho_{i}^{e f}}
$$

where PEcoal $_{i}$ and PEoilgas ${ }_{i}$ are the price of the input of coal and refined petroleum-gas in sector $\mathrm{i}$ in region $\mathrm{r}$ respectively.

Price relationship of the input of the aggregation of fossil fuels:

$$
\text { PEF }_{i} \cdot \text { QEF }_{i}=\text { PEcoal }_{i} \cdot \text { QEcoal }_{i}+\text { PEoilgas }_{i} \cdot \text { QEoilgas }_{i}
$$

\section{A1.1.7 The sixth level of the CES function of the aggregation of gas and refined petroleum}

The aggregation of gas and refined petroleum:

$$
\operatorname{QEoilgas}_{i}=\alpha_{i}^{p g} \cdot\left[\delta_{i}^{p g} \cdot \operatorname{QEgas}_{i}^{\rho_{i}^{p g}}+\left(1-\delta_{i}^{p g}\right) \cdot \operatorname{QEoil}_{i}^{\rho_{i}^{p g}}\right]^{1 / \rho_{i}^{p g}}
$$




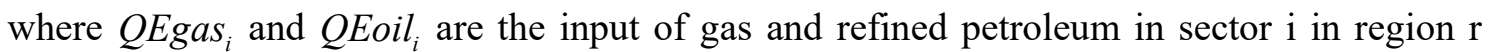
respectively, $\delta_{i}^{p g}$ and $\alpha_{i}^{p g}$ are the share parameter and efficiency parameter; $\rho_{i}^{p g}$ is the substitution elasticity parameter between the input of gas and refined petroleum, and $\sigma_{i}^{p g}=1 /\left(1-\rho_{i}^{p g}\right), \sigma_{i}^{p g}$ is the substitution elasticity between the input of gas and refined petroleum.

First order condition of optimal factor input:

$$
\frac{\text { PEgas }_{i}}{\text { PEoil }_{i}}=\frac{\delta_{i}^{p g}}{\left(1-\delta_{i}^{p g}\right)} \cdot\left(\frac{\text { EEoil }_{i}}{\text { QEgas }_{i}}\right)^{1-\rho_{i}^{p g}}
$$

where $\mathrm{PEgas}_{i}$ and $\mathrm{PEoil}_{i}$ are the price of the input of gas and refined petroleum in sector $\mathrm{i}$ in region $\mathrm{r}$ respectively.

Price relationship of the input of the aggregation of refined petroleum and gas:

$$
\text { PEoilgas }_{i} \cdot \text { QEoilgas }_{i}=\text { PEoil }_{i} \cdot \text { QEoil }_{i}+\text { PEgas }_{i} \cdot \text { QEgas }_{i}
$$

\section{A1.2 Trade module}

\section{A1.2.1 Export}

CET function is adopted to describe the allocation of supply between domestic market and export:

$Q A_{i}=\alpha_{i}^{t} \cdot\left[\delta_{i}^{t} \cdot Q D A_{i}^{\rho_{i}^{t}}+\left(1-\delta_{i}^{t}\right) \cdot Q E_{i}^{\rho_{i}^{t}}\right]^{1 / \rho_{i}^{t}}, \quad \rho_{i}^{t}>1$

where $Q D A_{i}$ and $Q E_{i}$ are the supply of commodity produced in sector i to domestic market and export respectively, $\delta_{i}^{t}$ and $\alpha_{i}^{t}$ are the share parameter and efficiency parameter; $\rho_{i}^{t}$ is the transformation elasticity parameter between domestic market supply and export, and $\sigma_{i}^{t}=1 /\left(\rho_{i}^{t}-1\right), \sigma_{i}^{t}$ is the transformation elasticity between domestic market supply and export.

First order condition:

$$
\frac{P D A_{\mathrm{i}}}{P E_{\mathrm{i}}}=\left(\frac{\delta_{\mathrm{i}}^{t}}{1-\delta_{\mathrm{i}}^{t}}\right) \cdot\left(\frac{Q E_{\mathrm{i}}}{Q D A_{\mathrm{i}}}\right)^{1-\rho_{\mathrm{i}}^{t}}
$$

where $P D A_{\mathrm{i}}$ and $P E_{\mathrm{i}}$ are the domestic price and export price of commodity produced in sector i.

Relationship of price: 
$P A_{i} \cdot Q A_{i}=P D A_{i} \cdot Q D A_{i}+P E_{i} \cdot Q E_{i}$

Exchange rate conversion between the price of export commodity in the global market and SAR:

$P E_{i}=\overline{P W E}_{i} \cdot E X R$

where $\overline{P W E}_{i}$ is the international market price of exported commodity i, EXR is the exchange rate.

\section{A1.2.2 Import}

CES function is adopted to describe the choice between domestic and import commodity:

$Q Q_{i}=\alpha_{i}^{q} \cdot\left[\delta_{i}^{q} \cdot Q D C_{i}^{\rho_{i}^{q}}+\left(1-\delta_{i}^{q}\right) \cdot Q M_{i}^{\rho_{i}^{q}}\right]^{1 / \rho_{i}^{q}}$

where $Q Q_{i}, Q D C_{i}$ and $Q M_{i}$ are the demand for composite commodity i, domestic commodity $\mathrm{i}$ and import commodity i respectively, $\delta_{i}^{q}$ and $\alpha_{i}^{q}$ are the share parameter and efficiency parameter; $\rho_{i}^{q}$ is the substitution elasticity parameter between domestic and import commodity, and $\sigma_{i}^{q}=1 /\left(1-\rho_{i}^{q}\right), \sigma_{i}^{q}$ is the substitution elasticity between domestic and import commodity.

First order condition:

$\frac{P D C_{i}}{P M_{i}}=\left(\frac{\delta_{i}^{q}}{1-\delta_{i}^{q}}\right) \cdot\left(\frac{Q M_{i}}{Q D C_{i}}\right)^{1-\rho_{i}^{q}}$

where $P D C_{i, r}$ is the price of domestic commodity i, $P M_{i, r}$ is the price of import commodity i.

Composite commodity price is the weighted mean of the prices of the domestic and import commodities:

$P Q_{i} \cdot Q Q_{i}=P D C_{i} \cdot Q D C_{i}+P M_{i} \cdot Q M_{i}$

where $P Q_{i}$ is the price of composite commodity i.

Exchange rate conversion between the price of import commodity in the international market and China:

$P M_{i}=\overline{P M W}_{i} \cdot\left(1+t m_{i}\right) \cdot E X R$ 
where $\overline{P M W}_{i}$ is the international market price of import commodity i, $t m_{i}$ is the import tariff rate of import commodity $i$.

\section{A1.3 Income and expenditure module}

\section{A1.3.1 Income and expenditure of households}

\section{A1.3.1.1 Income of households}

In this model, the households' income is composed of labor payment, capital revenue and transfer payments from government and foreign countries.

$$
Y H=\sum_{\mathrm{i}} W L \cdot Q L D_{i}+\operatorname{shifhk} \sum_{i} W K \cdot Q K D_{i}+\overline{T S G T O H}+\overline{T S E T O H}+E X R \cdot \overline{T S W T O H}
$$

where $Y H$ is the income of households, shifhk is the coefficient of the households' share in capital revenue, $\overline{T S G T O H}$ is transfer payments from government, $\overline{T S E T O H}$ is transfer payments from enterprises, $\overline{T S W T O H}$ is transfer payments from foreign countries.

\section{A1.3.1.2 Expenditure of households}

The consumption function of households is assumed as a Cobb-Douglas utility function in this model, which can derive the final consumption of households as the following equation:

$$
P Q_{i} \cdot Q H_{i}=s h r h_{i} \cdot m p c \cdot(1-t h) \cdot Y H
$$

where $Q H_{i}$ is the consumption of commodity i of households, $m p c$ is the marginal propensity to consume of the household, $s h r h_{i}$ is the share of the consumption of commodity $\mathrm{i}$ in the expenditure of households, th is the rate of household income tax .

The households' expenditure contains total final consumption:

$$
E H=\sum_{i} P Q_{i} \cdot Q H_{i}+t h \cdot Y H
$$

where $E H$ is the expenditure of households.

Accordingly, household saving is:

$H S A V=Y H-E H$

where $H S A V$ is household saving.

\section{A1.3.1.2 Income and expenditure of governments \\ Income of government}


The government's income in region $r$ is composed of tariff, capital revenue and carbon tax.

$Y G=\sum_{i} t_{\text {tcind }} \cdot P A_{i} \cdot Q A_{i}+\sum_{i} t m_{i} \cdot Q M_{i} \cdot \overline{P M W}_{i} \cdot E X R+t h \cdot Y H+t e \cdot s h i f e k \cdot \sum_{i} W K_{i} \cdot Q K D_{i}+E X R \cdot \overline{T S W T O G}+T O C T R$ (33)

where $Y G$ is the income of government, tcind $_{i}$ is the rate of indirect tax paid to government of industry i, shife $k$ is the coefficient of enterprises' share in total capital revenue, te is the rate of enterprise income tax, $\overline{T S W T O G}$ is the transfer payments from foreign countries to government, TOCTR is carbon tax revenue.

\section{Expenditure of government}

The government's expenditure includes commodity consumption, energy subsidy, and transfer payments to the local government.

$$
E G=\sum_{i} P Q_{i} \cdot Q G_{i}+\overline{T S G T O H}+\overline{T S G T O E}+E X R \cdot \overline{T S G T O W}
$$

where $E G$ is the central government's expenditure in region r, $\overline{T S G T O H}, \overline{T S G T O E}$ and $\overline{\text { TSGTOW }}$ are government's transfer payments to households, enterprises and foreign countries, respectively.

In the equation above, consumption demand of the central government in region $r$ is:

$$
P Q_{i} \cdot Q G_{i}=\operatorname{shrg} \cdot \operatorname{mpcg} \cdot Y G
$$

where $\operatorname{shrg}_{i}$ is the spending share of government's consumption of commodity i, mpcg is government's marginal propensity to consume.

Accordingly, government saving is:

$$
G S A V=Y G-E G
$$

where $G S A V$ is government saving.

\section{A1.3.1.3 Income and expenditure of enterprises}

\section{(1) Income of enterprises}

The enterprises' income includes capital revenue and transfer payments from the central government.

$Y E N T=\operatorname{shifek} \sum_{i} W K_{i} \cdot Q K D_{i}+\overline{T S G T O E}$ 
where $Y E N T_{r}$ is the income of enterprises, shifek is the coefficient of the enterprises' share in capital revenue.

\section{(2) Expenditure of enterprises}

The enterprises' expenditure consists of the enterprise income taxes paid to the government and the transfer payments to the households.

$E X E N T=$ te $\cdot$ fhifek $\cdot \sum_{i} W K_{i} \cdot Q K D_{i}+\overline{T S E T O H}$

where EXENT is the expenditure of enterprises.

Accordingly, enterprise saving is:

$E S A V=Y E N T-E X E N T$

where $E S A V$ is enterprise saving.

\section{A1. 4 Carbon emission and carbon tax module}

\section{A1.4.1 Carbon emission}

Carbon emission coefficient (ton $\mathrm{CO}_{2} / 10,000$ yuan) of three kinds of fossil fuel inputs (coal, refined petroleum, gas) of each industry in this model can be obtained from the data of the base year, which can derive the calculation of carbon emission as the following equations:

$$
\begin{aligned}
& \text { QEMIS }_{i}=\operatorname{coef}_{\text {coal }} \cdot \text { QEcoal }_{i}+\operatorname{coef}_{\text {oil }} \cdot \text { QEoil }_{i}+\operatorname{coef}_{\text {gas }} \cdot \text { QEgas }_{i} \\
& \text { QTEMIS }=\sum_{i} \text { QEMIS }_{i}
\end{aligned}
$$

where $Q E M I S_{i}$ is the amount of carbon emission of industry i, QTEMIS is the total amount of national carbon emissions.

\section{A1.4.2 Carbon tax}

$$
\begin{aligned}
& C T R_{i}=c t a x \cdot \text { QEMIS }_{i} \\
& \text { TOCTR }=\sum_{i} C T R_{i}
\end{aligned}
$$

where ctax is the carbon tax rate, $\mathrm{CTR}_{i}$ is the carbon tax payable of sector $\mathrm{i}$.

\section{A1.4.3 Adjustments of the production function equation}

The first order condition of the fifth level of the production function should be adjusted as: 
$\frac{\left(1+\text { ctax } \text { coef }_{\text {coal }}\right) \cdot \text { PEcoal }_{i}}{\text { PEoilgas }_{i}}=\frac{\delta_{i}^{e f}}{\left(1-\delta_{i}^{e f}\right)} \cdot\left(\frac{\text { QEoilgas }_{i}}{\text { QEcoal }_{i}}\right)^{1-\rho_{i}^{e f}}$

Meanwhile, the price relationship of the input of the aggregation of fossil fuels should be adjusted as:

$\mathrm{PEF}_{i} \cdot \mathrm{QEF}_{i}=\left(1+\operatorname{ctax} \cdot \operatorname{coef}_{\text {coal }}\right) \cdot \mathrm{PEcoal}_{i} \cdot \mathrm{QEcoal}_{i}+$ PEoilgas $_{i} \cdot$ QEoilgas $_{i}$

The first order condition of the sixth level of the production function should be adjusted as:

$\frac{\left(1+\operatorname{ctax} \cdot \operatorname{coef}_{\mathrm{gas}}\right) \cdot \text { PEgas }_{i}}{\left(1+\operatorname{ctax} \cdot \operatorname{coef}_{\text {oil }}\right) \cdot \text { PEoil }_{i}}=\frac{\delta_{i}^{p g}}{\left(1-\delta_{i}^{p g}\right)} \cdot\left(\frac{\text { QEoil }_{i}}{\text { QEgas }_{i}}\right)^{1-\rho_{i}^{p g}}$

Meanwhile, the price relationship of the input of the aggregation of refined petroleum and gas should be adjusted as:

PEoilgas $_{i, r} \cdot$ QEoilgas $_{i, r}=\left(1+\operatorname{ctax} \cdot \operatorname{coef}_{\text {oil }}\right)$ PEoil $_{i, r} \cdot$ QEoil $_{i, r}+\left(1+\operatorname{ctax} \cdot \operatorname{coef}_{\mathrm{gas}}\right) \cdot$ PEgas $_{i, r} \cdot$ QEgas $_{i, r}(20)$

\section{A1.5 Market clearing and macroeconomic closure module}

\section{A1.5.1 Commodity market clearing}

For the non-energy commodities as intermediate inputs, we have:

$Q Q_{i}=\sum_{j} i c a_{i, j} \cdot \operatorname{QINTA}_{j}+Q H_{i}+Q G_{i}+Q I N V_{i}+\overline{Q S T O C K}_{i}, \quad i \in N E$

where $Q I N V_{i}$ is the demands for commodities i used as investment, $\overline{Q S T O C K}_{i}$ is the demands for commodities i used as stock.

For energy commodities, we have:

$$
Q Q_{i}=\sum_{j} Q E_{i, j}+Q H_{i}+Q G_{i}+Q I N V_{i}+\overline{Q S T O C K}_{i}, \quad i \in E
$$

Where $Q E_{i, \mathrm{j}}$ is the inputs of different energy commodities of every industry, here i refers to four kinds of energy commodities inputs of industry j, i.e., $Q E E_{\mathrm{j}}, Q_{E c o a l}, Q E_{o i l}, Q_{j}$ gas $_{j}$

\section{A1.5.2 Factor market clearing}

The labor supply equal to the labor demand:

$$
\overline{Q L S}=\sum_{i} Q L D_{i}
$$

For capital, the same assumption as follows: 


$$
\overline{Q K S}=\sum_{i} Q K D_{i}
$$

\section{A1.5.3 Governmental budget balance}

Government savings is the difference value of governmental income and governmental expenditure, see equation (42).

\section{A1.5.4 Investment and saving balance}

This model is a savings-driven model in which total investment is decided by total savings:

$$
T O T I N V+\sum_{i} P Q_{i} \cdot \overline{Q S T O C K}_{i}=H S A V+E S A V+G S A V+E X R \cdot F S A V+W A L R A S
$$

$$
P Q_{i} \cdot Q I N V_{i}=\operatorname{shareinv}_{i} \cdot T O T I N V
$$

where TOTINV is total investment, FSAV is foreign savings, WALRAS is dummy variable. shareinv $_{i}$ is the share of commodity i used as investment in the total investment.

\section{A1.5.4 Foreign income and expenditure balance}

The difference value of income and expenditure of foreign countries is foreign savings.

$$
\sum_{i} P W M_{i} \cdot Q M_{i}+\overline{T S G T O W}=\sum_{i} P W E_{i} \cdot Q E_{i}+\overline{T S W T O G}+\overline{T S W T O H}+F S A V
$$

\section{A1.5.6 Macroeconomic closure}

The "neoclassical closure" rule is adopted in this model. In this model, all the savings are transformed into investment, and the total investment equals total savings endogenously. Labor supply at the national level is exogenous, and all factors are fully employed in the whole economy.

The nominal GDP can be calculated from the following equation:

$$
\begin{array}{r}
G D P V A=\sum_{i} P Q_{i} \cdot\left(Q H_{i}+Q G_{i}+Q I N V_{i}+\overline{Q S T O C K}_{i}\right)+\sum_{i} P E_{i} \cdot Q E_{i}-\sum_{i} P M_{i} \cdot Q M_{i} \\
+\sum_{i} t m_{i} \cdot Q M_{i} \cdot \overline{P M W}_{i} \cdot E X R
\end{array}
$$

where GDPVA is the nominal GDP.

The real GDP can be calculated as follows:

$$
G D P=\sum_{i}\left(Q H_{i}+Q G_{i}+\mathrm{QINV}_{i}+\overline{Q S T O C K}_{i}\right)+\sum_{i} Q E_{i}-\sum_{i}\left(Q M_{i}-t m_{i} \cdot Q M_{i} \cdot \overline{P M W}_{i} \cdot E X R\right)
$$

where GDP is the real GDP.

Therefore, the GDP index can be obtained by the following equation: 


$$
P G D P=\frac{G D P}{G D P V A}
$$

Where $R G D P$ is the GDP index.

Meanwhile, the CPI can be obtained as follows:

$$
C P I=\frac{\sum_{i} P Q_{i} \times Q H 0_{i}}{\sum_{i} P Q 0_{i} \times Q H 0_{i}}
$$

Where $C P I$ is the consumer price index.

In the model, household welfare variation is measured by using the Hicksian equivalent variation $(\mathrm{EV})$.

\section{A1.6 Dynamic mechanism}

This model is a recursive dynamic CGE model, and the dynamic mechanism includes labor supply growth, increase of total factor productivity (TFP) and capital accumulation.

\section{A1.6.1 Labor supply growth}

Labor supply in different periods is described as:

$$
\overline{T T Q L}_{t+1}=(1+\operatorname{lgow}) \overline{T T Q L}_{t}
$$

where lgow is the annual growth rate of labor supply.

\section{A1.6.2 TFP increase}

In the model, TFP increase is represented by the change of technology parameter in the second level of the CES production function.

$$
\alpha_{i t+1}^{v a}=(1+\operatorname{tgrow}) \cdot \alpha_{i t}^{v a}
$$

Where tgrow is the annual growth rate of TFP.

\section{A1.6.3 Capital Accumulation}

We adopted the method used by James Thurlow ${ }^{[3]}$ to describe the capital accumulation in different periods. In the model, total capital supply is endogenous in a given period and the total available capital is determined by the previous period's capital stock and new investment.

In this model, the new capital stock resulting from the previous investment is allocated across sectors in proportion to each sector's share in aggregate capital income, and these proportions are adjusted by the ratio of each sector's profit rate to the average profit rate for the whole economy. 


$$
W K A_{t}=\sum_{i} \frac{Q K D_{i, \mathrm{t}}}{\sum_{i} Q K D_{i, \mathrm{t}}} \cdot W K_{i, t}
$$

Where $W K A_{t}$ is the average economy-wide rental rate of capital at time period t.

$$
\operatorname{sharenk}_{i, t}=\frac{Q K D_{i, \mathrm{t}}}{\sum_{i} Q K D_{i, \mathrm{t}}} \cdot\left[1+\beta_{i} \cdot\left(\frac{W K_{i, t}}{W K A_{t}}-1\right)\right]
$$

Where sharenk $k_{i, t}$ is the share of the new capital investment of industry $\mathrm{i}$ at period $\mathrm{t}, \beta_{i}$ is the inter-sectoral mobility coefficient of investment. The value of $\beta_{i}$ can be chosen from 0 to 1 , $\beta_{i}$ is 0 means there is no inter-sectoral mobility of investment, whereas $\beta_{i}$ is 1 means there is full inter-sectoral mobility of investment.

$$
P K_{t}=\sum_{i} P Q_{i, t} \cdot \frac{Q I N V_{i, t}}{\sum_{i} Q I N V_{i, t}}
$$

Where $P K_{t}$ is the price of capital at period t.

$$
\operatorname{QIND}_{i, t}=\operatorname{sharenk}_{i, t} \cdot \frac{\sum_{i} P Q_{i, t} \cdot Q I N V_{i, t}}{P K_{t}}
$$

Where $Q I N D_{i, t}$ is the new-added capital of industry $\mathrm{i}$ at period t.

$$
T Q K A_{i, t+1}=T Q K A_{i, t} \cdot\left(1+\frac{Q I N D_{i, t}}{T Q K A_{i, t}}-d e p r_{i}\right)
$$

Where $T Q K A_{i, t+1}$ is the capital stock of industry $\mathrm{i}$ at time period $\mathrm{t}+1$, depr $r_{i}$ is the depreciation rate of industry $i$.

$$
T Q K_{t+1}=T Q K_{\mathrm{t}} \cdot\left(1-\mathrm{depr}_{i}\right)+\sum_{\mathrm{i}} Q I N D_{i}
$$

Where $T Q K_{t+1}$ is the new aggregate quantity of capital at time period $\mathrm{t}+1$.

\section{A1.7 Data and parameters}

In this paper, the benchmark year for the CGE model is 2012, and a SAM that is suitable to the structure of the CGE model has been constructed as the database. Here, the "top-down method" was adopted for constructing the SAM. First, a macro SAM was compiled to provide a consistent macroeconomic data framework. Second, based on the macro SAM, a micro SAM was compiled based on the research purpose. The published 2012 input-output tables of China $^{[9]}$ provided the basic data source for compiling the SAM, and all 42 sectors in the 2012 input-output tables of China were reorganized into 16 sectors to construct the micro SAM. 
In addition to the SAM, there are two types of parameters that should be estimated before the CGE model can be used for policy analysis: one is a share parameter, such as consumer expenditure share, and the other is an elasticity parameter, such as the elasticity of substitution in the production function. The share parameters can be estimated from the SAM using a calibration method that assumes the benchmark year represented by the SAM is an equilibrium solution for the CGE model, but the elasticity parameters must be obtained based on the relevant literature ${ }^{[10-12]}$. The $\mathrm{CO}_{2}$ emission factors from fossil fuels are calculated based on IEA statistical data ${ }^{[13]}$. 


\section{Appendix B - The TIMES Model}

\section{B1. Introduction}

The TIMES model is an energy sector optimization model built on the Reference Energy System (RES). The model is designed to minimize the total cost of the entire energy system to meet the projected end-use energy demand satisfying technical, resource, environmental and any other constraints. It selects an optimal combination of energy production, transformation, transportation and utilization technologies accounting for their investment, operation and maintenance and any other associated costs. It is capable to simulate a range of scenarios related to energy and environmental policies. The TIMES modeling system has a series of modules, such as demand module, resource module, production module, transformation module, utilization module. The demand module projects end-use energy demand using demand drivers, such as GDP and population growth rates, urbanization rate, and evolutions in energy utilization technologies (light bulbs, roof/wall/window insulations, cooking stoves, refrigerators, heating and cooling devices, etc.). The demand module is simplistic. The relationship between energy demands and corresponding drivers are established through regression analysis using historical data. The resource module provides information on energy extraction costs, such as costs of coal mining, natural gas drilling and production, crude oil drilling and production considering resource potential, costs of technologies used. It also includes production of electricity from primary sources (hydro, nuclear, wind, solar, geothermal). Power generation costs from various primary sources are derived from investment costs, economic lives of generation technologies, resource availability profiles (availability factors). The energy conversion module does the same when primary energy resources (e.g., coal, natural gas) are converted to another form of energy, such as electricity from coal and gas; refinery petroleum products from crude oil, processed gas from natural gas, charcoal from fuel wood, production of ethanol and biodiesel. It also includes many physical conversions of energy commodities such as raw coal washing and dressing. The various modules are briefly discussed here as presenting all equations of the TIMES model system will be too long. ${ }^{8}$ Instead of presenting detailed equations of the TIMES modeling system, below we present key characteristics of the Chinese energy system reflected in the TIMES model used for this study.

\section{B1.1 Resource module}

${ }^{8}$ Interested readers could refer to the technical manual of TIMES modeling system (Richard Loulou et al. 2005). 
Resource supply curves are derived for various domestic producers by region (e.g., North China, East China, Northeast China, South Central China, Southeast and Western China). The curve accounts several factors such as reserve capacities, annual production capacities, production technologies and corresponding costs. The selection of energy resources is purely based on the cost. The short-term cumulative cost curve has an upward trend with quantity reflecting the fact that exploitation costs increase with depletion of reserves. High-quality mineral deposits with low exploitation costs are preferentially exploited. As the exploitation is advanced, other reserves are gradually used. In the long-run, the cost curve has an S-shape to reflect the exploitation of reserves in different stages. The production cost function for a given total reserve can be represented by a series of cost curves. Different resource grades have different unit production costs. The model has resource supply costs for every depletable resource (coal, crude oil, natural gas) in each region. Different production costs in different regions lead to significant disparities in regional resources. Being renewable, primary electricity sources are represented differently in the form of levelized costs of electricity generation.

The cumulative supply and the cost are shown in the equations below.

$$
\begin{aligned}
& Z_{t}=\sum_{i=1}^{\mathrm{J}} q_{i} \\
& C(q, z)=\min _{x_{i}} \sum_{i=1}^{J} c_{i} \times x_{i} \\
& x_{i} \leq R_{i}, \text { and } \forall i, \quad q_{\mathrm{i}}=\sum_{t=1}^{\mathrm{t}} x_{i t}
\end{aligned}
$$

Where $Z_{t}$ is the cumulative production of all mineral reserve lands based on time $t, q_{i}$ is the cumulative production of the $i_{\text {th mineral reserve land. }} C(q, z)$ is the total production cost, ${ }_{i}$ is the amount of the resource mined in the ${ }^{i}$ th mineral reserve land in this period, $R_{i}$

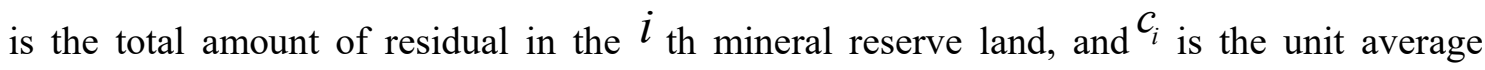
production cost in the $i$ th mineral reserve land. The total cost $\mathrm{C}$ is relevant to $\mathrm{q}$ and $\mathrm{z}$ because these two parameters will influence the unit average production cost. 
In China, $85 \%$ of the total coal reserves are located in western and northern China; about $10 \%$ of total reserves are located in southern China ${ }^{1]}$. Based on discussion with experts, coal supply capacity is expected to peak at around 4 billion tons during 2025-2030 ${ }^{[2]}$. Domestic production of coal has been declining whereas supply from imports is increasing due to quality adjusted cost competitiveness of imported coal.

Crude oil reserves are mainly concentrated in several basins. Production comes from conventional and unconventional sources. Conventional oil supply capacity has already reached its peak. Production from unconventional sources is still expected to grow. Currently, more than $60 \%$ of total oil demand is supplied through imports, imports share is estimated to increase to $79 \%$ by $2035^{[3]}$.

Natural gas reserves are located mainly in Tarim and Sichuan basins, therefore, most of the production comes from western China (see Table B1). Compared to demand, domestic supply is small. China's imports dependency on natural gas will increase rapidly in future.

Table B1. Natural gas reserves by basins (thousand billion tons)

\begin{tabular}{crrrr}
\hline Categories & Basins & $\begin{array}{c}\text { Prospect } \\
\text { Resource } \\
\text { Amount }\end{array}$ & $\begin{array}{c}\text { Geological } \\
\text { Resource Amount }\end{array}$ & $\begin{array}{c}\text { Recoverable } \\
\text { Resource } \\
\text { Amount }\end{array}$ \\
\hline I & Tarim & 11.34 & 8.86 & 5.86 \\
II & Sichuan & 7.19 & 5.37 & 3.42 \\
& Ordos & 10.7 & 4.67 & 2.9 \\
& East China sea & 5.1 & 3.64 & 2.48 \\
& Qaidam & 2.63 & 1.6 & 0.86 \\
& Songliao & 1.8 & 1.4 & 0.76 \\
& Yingge sea & 2.28 & 1.31 & 0.81 \\
& Qiongdongnan & 1.89 & 1.11 & 0.72 \\
Bohai Bay & 2.16 & & 0.62 \\
\hline
\end{tabular}

\section{B2. Energy processing and conversion module}

The energy conversion module includes petroleum refining, coal washing and dressing, coal liquefaction/gasification, natural gas processing, production of biofuels and production of electricity and heat from fossil fuels. The Chinese petroleum refinery system is characterized as a large network of small-scale refineries. The main refinery plants are configured for heavy crude oil with a relatively high proportion of catalytic cracking.

Refinery capacities to produce relatively cleaner petroleum products such as low-sulfur gasoline and diesel are limited.

Coal washing and dressing is needed for efficient use of coal because Chinese coal has higher ash contents. Industrial boilers and residential stoves use a large amount of low-quality raw 
coal, which emits higher amounts of harmful pollutants. Therefore, coal washing and dressing is needed. Coal gasification is a source of natural gas in China. Gasification technologies used include pure oxygenation, hydro-gasification and steam gasification.

Coal and natural gas are the main sources of thermal generation in China. The setting of coal power technology in the model includes conventional power generation technologies such as pulverized combustion and circulating fluidized bed combustion and advanced supercritical and ultra-supercritical technologies. It also includes integrated gasification combined cycle (IGCC) technology and cogeneration technology. The natural gas power generation technology includes gas turbine and combined cycle technologies. The heat production is mainly for industrial application and district heating. Coal-fired boilers account for almost $80 \%$ of the total industrial boilers. Data on thermal efficiency and capital costs of thermal power plants are provided in Table B2.

Table B2. Thermal power supply efficiency,technology and unit investment

\begin{tabular}{|c|c|c|c|}
\hline $\begin{array}{r}\text { Unit generating } \\
\text { mode }\end{array}$ & $\begin{array}{r}\text { Power } \\
\text { generation } \\
\text { technology }\end{array}$ & $\begin{array}{r}\text { Power } \\
\text { generation } \\
\text { efficiency }(\%)\end{array}$ & $\begin{array}{r}\text { Capital cost } \\
(\text { Yuan } / \mathbf{k W})\end{array}$ \\
\hline \multirow[t]{5}{*}{$\begin{array}{r}\text { Coal-fired power } \\
\text { generation }\end{array}$} & $\begin{array}{r}\text { Ultra- } \\
\text { supercritical }\end{array}$ & $45 \% \sim 47 \%$ & $3600 \sim 3800$ \\
\hline & Supercritical & $41 \% \sim 42 \%$ & $3700 \sim 3850$ \\
\hline & Subcritical & $38 \% \sim 39 \%$ & $4400 \sim 4600$ \\
\hline & $\begin{array}{r}\text { Circulating } \\
\text { fluidized bed }\end{array}$ & $35 \% \sim 40 \%$ & $4500 \sim 6000$ \\
\hline & IGCC & $40 \% \sim 43 \%$ & $8000 \sim 10000$ \\
\hline \multirow[t]{2}{*}{$\begin{array}{l}\text { Gas power } \\
\text { generation }\end{array}$} & $\begin{array}{r}\text { Natural gas } \\
\text { boiler }\end{array}$ & Less than $35 \%$ & $3100 \sim 3400$ \\
\hline & NGCC & $55 \% \sim 67 \%$ & $3282 \sim 3350$ \\
\hline $\begin{array}{l}\text { Fuel power } \\
\text { generation }\end{array}$ & $\begin{array}{r}\text { Direct } \\
\text { combustion } \\
\text { boiler }\end{array}$ & Less than $25 \%$ & $3300 \sim 3500$ \\
\hline $\begin{array}{r}\text { Coal gangue } \\
\text { power } \\
\text { generation }\end{array}$ & $\begin{array}{r}\text { Circulating } \\
\text { fluidized bed }\end{array}$ & $37 \%$ & $4500 \sim 6000$ \\
\hline $\begin{array}{r}\text { Biomass power } \\
\text { generation }\end{array}$ & $\begin{array}{r}\text { Biomass direct } \\
\text { combustion }\end{array}$ & $23 \%$ & $6500 \sim 8500$ \\
\hline $\begin{array}{r}\text { Unit generating } \\
\text { mode }\end{array}$ & $\begin{array}{r}\text { Biomass } \\
\text { gasification }\end{array}$ & $36 \%$ & $6500 \sim 12000$ \\
\hline
\end{tabular}

Note: The data needed for the power sector sub-module are obtained from sources including China Electric Power Yearbook (2010-2013) ${ }^{[5]-[8], ~ C h i n a ~ E n e r g y ~ S t a t i s t i c a l ~ Y e a r b o o k ~(2006-~}$ 2014) ${ }^{[9]-[17], C h i n a ~ E l e c t r i c ~ P o w e r ~ S t a t i s t i c s ~ I n f o r m a t i o n ~ C o l l e c t i o n ~(2010-2013)[18]-~}$ 
${ }^{[21]}$ „China's Energy Science and Technology Development Outlook for the 21st Century ${ }^{[22]}$, Electric Power Supervision Annual Report 2010[23], and other literature on technical parameters. and economic analysis of power production.

\section{B3. End-use energy demand module}

The demand for end-use energy services in our TIMES model is classified into four major final demand sectors: buildings, industrial, transportation and agricultural. End-use energy demands are projected based on the relationships between energy demand and corresponding drivers. The relationships are established based on statistical analysis (e.g., regression analysis) using historical data. The end-use demand forecasts differ across the final demand sectors. The transportation sector is divided into different modes: road, rail, air and water. Each mode has two types of transportation services: passenger and freight. The industrial sector is divided into sub-sectors and technologies. The building sector is divided into: urban residential buildings, rural residential buildings, general public buildings and large public buildings. In each type of building, end-use energy demand is divided into heating, refrigerating, lighting, cooking, hot water and electronic equipment.

In the base year (2015), the model is calibrated with detailed data. The data for sectoral and sub-sectoral energy consumption are compiled from Energy Balance and the Industrial Statistical Yearbook. Table B3 shows data used in the base year by industrial sector category.

Table B3 Energy consumption of each sub-sector of the industrial sector in the base year

\begin{tabular}{|l|r|r|r|r|r|r|}
\hline & \multicolumn{1}{|c|}{ Total } & \multicolumn{1}{l}{ Coal } & Oil & Gas & Electricity & \multicolumn{1}{l|}{ Heat } \\
\hline Chemical & 229.23 & 93.86 & 47.60 & 28.00 & 38.65 & 21.12 \\
\hline Non-metal & 228.38 & 162.96 & 26.95 & 7.92 & 30.09 & 0.45 \\
\hline Non-ferrous metal & 65.03 & 15.27 & 5.64 & 2.36 & 38.46 & 3.31 \\
\hline Paper & 28.47 & 15.72 & 0.89 & 0.23 & 6.58 & 5.06 \\
\hline Textile & 36.66 & 11.97 & 1.45 & 0.37 & 15.69 & 7.18 \\
\hline Black metal & 473.39 & 76.92 & 2.69 & 43.34 & 56.68 & 8.44 \\
\hline Others & 498.14 & 116.30 & 119.58 & 33.59 & 161.85 & 27.13 \\
\hline Total & 1559.30 & 493.00 & 204.80 & 115.80 & 348.00 & 72.70 \\
\hline
\end{tabular}

Transport energy demands are derived based on vehicle type, fuel type, technical efficiency and fuel economy and different emission standards. In the base year, transport energy demands are as shown in Table B4.

Table B4 Transportation sector data for the base year

\begin{tabular}{lr}
\hline Road gasoline/Mt & 99.47 \\
Highway diesel/Mt & 115.3 \\
Railway diesel/Mt & 9.79 \\
\hline
\end{tabular}




\begin{tabular}{lr}
\hline Railway power / 100 million kWh & 3.77 \\
Waterway diesel/Mt & 11.29 \\
Waterway fuel oil/Mt & 21.42 \\
Aviation kerosene / Mt & 25.6 \\
\hline
\end{tabular}

Source: Wang (2011).

The building sector is divided into urban residential, rural residential, general public construction and large-scale public construction according to the type of building. The enduse energy demands are space heating, cooling, lighting, cooking, hot water and other equipment. The base year data are provided in Table B5.

Table B5 Baseyear data for the building sector (unit: Mtce)

\begin{tabular}{ccccc}
\hline $\begin{array}{c}\text { Base year calibration } \\
\text { (Mtce) }\end{array}$ & $\begin{array}{c}\text { general } \\
\text { public } \\
\text { construction }\end{array}$ & $\begin{array}{c}\text { large-scale } \\
\text { public } \\
\text { construction }\end{array}$ & $\begin{array}{c}\text { urban } \\
\text { residential }\end{array}$ & $\begin{array}{c}\text { rural } \\
\text { residential }\end{array}$ \\
\hline $\begin{array}{c}\text { Heating } \\
\text { Refrigeration }\end{array}$ & 5141 & 855 & 10971 & 5412 \\
Lighting & 1490 & 480 & 516 & 130 \\
Others & 1055 & 313 & 544 & 523 \\
Cooking and hot & 1073 & 149 & 787 & 361 \\
$\quad$ water & 1363 & 250 & 4267 & 2296 \\
Total & 10121 & 2048 & 17086 & 8721 \\
\hline
\end{tabular}

The main sources of energy demand data are energy balance tables available from China's energy statistical yearbook. For energy consumption in the industrial sub-sectors and technologies we used several sources such as China Statistical Yearbook 2006-2011 [24]-[29],

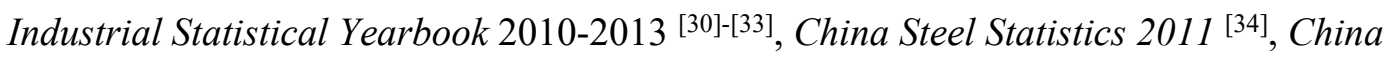
Chemical Industry Yearbook ${ }^{[35][36]}$, China Nonferrous Metals Industry Yearbook ${ }^{[37][38],}$ China Energy Statistical Yearbook 2006-2013 [39]-[42]. We also use technical parameter documents on production lines of major industrial sectors, as well as calculation and collation from related literature. The data of the transport sector are from: Research into China's Medium and Long-Term Development Strategy on Traffic and Transportation ${ }^{[43]}$, Automotive Energy Outlook 2012 [44], China Transport Yearbook ${ }^{[45]-[47], ~ C h i n a ~ B u l l e t i n ~ o n ~ M o t o r ~}$ Vehicles Pollution Prevention, China Energy Statistical Yearbook 2010-2013, as well as data research and calculation based on major literature. For the building sector, the data sources include The Annual Development and Research Report on Building Energy Efficiency in 
China (2008-2013) ${ }^{[47]}$, Chapter V Assessment on the Construction Industry in The Fifth

IPCC Assessment Report, as well as the summary and calculation of relevant literature.

\section{Appendix References}

[1] National Bureau of Statistics. 2017. China Statistical Yearbook 2017. Beijing: China Statistics Press, 2017.

[2] Han S, Chen H, Long R, Cui X. Peak coal in China: A literature review. Resource Conserve Recycle. 2018 Feb 1; 129: 293-306.

[3] BP. 2017.BP energy outlook 2017,2017.

[5] China Electric Power Yearbook Editorial Board. 2010. China Electric Power Yearbook. Beijing: China Electric Power Press, 2010.

[6] China Electric Power Yearbook Editorial Committee. 2011. China Electric Power Yearbook. Beijing: China Electric Power Press, 2011.

[7] China Electric Power Yearbook Editorial Board. 2012. China Electric Power Yearbook. Beijing: China Electric Power Press, 2012.

[8] China Electric Power Yearbook Editorial Committee. 2013. China Electric Power Yearbook. Beijing: China Electric Power Press, 2013.

[9] National Bureau of Statistics. China Energy Statistical Yearbook 2006. Beijing: China Statistics Press, 2006.

[10] National Bureau of Statistics. China Energy Statistics Yearbook 2007. Beijing: China Statistics Press, 2007.

[11] National Bureau of Statistics. China Energy Statistical Yearbook 2008. Beijing: China Statistics Press, 2008.

[12] National Bureau of Statistics. China Energy Statistics Yearbook 2009. Beijing: China Statistics Press, 2009.

[13] National Bureau of Statistics. China Energy Statistics Yearbook 2010. Beijing: China Statistics Press, 2010.

[14] National Bureau of Statistics. China Energy Statistics Yearbook 2011. Beijing: China Statistics Press, 2011.

[15] National Bureau of Statistics. China Energy Statistics Yearbook 2012. Beijing: China Statistics Press, 2012.

[16] National Bureau of Statistics. China Energy Statistics Yearbook 2013 Beijing: China Statistics Press, 2013.

[17] National Bureau of Statistics. China Energy Statistics Yearbook 2014 Beijing: China Statistics Press, 2014.

[18] China Electricity Council, China Electricity Statistics Collection. 2011. Beijing: 2011 
[19] China Electricity Council. China Power Statistics Compilation. 2012. Beijing: 2012

[20] China Electricity Council. China Power Statistics Compilation. 2013. Beijing: 2013

[21] China Electricity Council. China Power Statistics Compilation. 2014. Beijing: 2014

[22] Tsinghua University.Wang.China's Energy Science and Technology Development Outlook for the 21st Century.Tsinghua University Press Publishing.

[23] National Electricity Regulatory Commission. Electric Power Supervision Annual Report 2010

[24] National Bureau of Statistics. 2006. China Statistical Yearbook 2006. Beijing: China Statistics Press, 2006.

[25] National Bureau of Statistics. 2007. China Statistical Yearbook 2007. Beijing: China Statistics Press, 2007.

[26] National Bureau of Statistics. 2008. China Statistical Yearbook 2008. Beijing: China Statistics Press, 2008.

[27] National Bureau of Statistics. 2009. China Statistical Yearbook 2009. Beijing: China Statistics Press, 2009.

[28] National Bureau of Statistics. 2010. China Statistical Yearbook 2010. Beijing: China Statistics Press, 2010.

[29] National Bureau of Statistics. 2011. China Statistical Yearbook 2011. Beijing: China Statistics Press, 2011.

[30] Department of Industrial Statistics, National Bureau of Statistics. China Industrial Statistical Yearbook 2010. Beijing: China Statistics Press, 2010.

[31] Department of Industrial Statistics, National Bureau of Statistics. China Industrial Statistical Yearbook 2011. Beijing: China Statistics Press, 2011.

[32] Department of Industrial Statistics, National Bureau of Statistics. China Industrial Statistics Yearbook 2012. Beijing: China Statistics Press, 2012.

[33] Department of Industrial Statistics, National Bureau of Statistics. China Industrial Statistics Yearbook 2013. Beijing: China Statistics Press, 2013.

[34] China Iron and Steel Association. China Steel Statistics 2011. Beijing: China Iron and Steel Industry Association Information Statistics Department, 2011.

[35] Editorial Office of China Chemical Industry Yearbook. China Chemical Industry Yearbook 2005-2006. Beijing: China Chemical Information Center, 2007.

[36] Editorial Office of China Chemical Industry Yearbook. China Chemical Industry Yearbook 2010 (upper, middle and lower). Beijing: China Chemical Information Center, 2012.

[37] China Nonferrous Metals Industry Association. China Nonferrous Metals Industry Yearbook 2006. Beijing: China Nonferrous Metals Industry Yearbook Editorial Board, 2006. 
[38] China Nonferrous Metals Industry Association. China Nonferrous Metals Industry Yearbook 2013. Beijing: China Nonferrous Metals Industry Yearbook Editorial Board, 2014. [39] National Bureau of Statistics. China Energy Statistics Yearbook 2006. Beijing: China Statistics Press, 2006.

[40] National Bureau of Statistics. China Energy Statistics Yearbook 2011. Beijing: China Statistics Press, 2011.

[41] National Bureau of Statistics. China Energy Statistics Yearbook 2012. Beijing: China Statistics Press, 2012.

[42] National Bureau of Statistics. China Energy Statistics Yearbook 2013. Beijing: China Statistics Press, 2013.

[43] Wang Derong, Research on Medium and Long-term Development Strategy of China's Transportation, 1st Edition. Beijing: China Market Press, 2014.

[44] China Automotive Energy Research Center, Tsinghua University. Automotive Energy Outlook 2012. Beijing: Science Press, 2012.

[45] China Communications Yearbook. China Communications Yearbook 2011. Beijing: China Communications Yearbook, 2011

[46] China Communications Yearbook. China Communications Yearbook 2012. Beijing: China Communications Yearbook, 2012

[47] China Communications Yearbook. China Communications Yearbook 2013. Beijing: China Communications Yearbook, 2013 


\section{Appendix C: Detailed Methodology to Link CGE and TIMES Models}

This appendix provides a detailed methodology used to link the CGE and TIMES models. The output of CGE models is used in the TIMES model to revise its projections for energy demand at the sectoral, sub-sectoral and technological levels. The growth of energy demand by fuel type (i.e., coal, oil and natural gas) is reflected in the CGE model. The process continues until the growth rates of energy commodity demand are close enough between two models.

\section{C1. Linking TIMES to CGE}

The TIMES model takes projections of economic drivers, such as GDP, sectoral outputs, energy prices to revise its energy demand at the sectoral, sub-sectoral and technological levels. Below, we discuss how this has been done sector by sector.

\section{C.1.1 Energy demand in the commercial sectors/sub-sectors in TIMES}

The TIMES model has a commercial sector for the rural and urban region, and heating/cooling/ lighting/hot water/equipment technologies as presented in Table B1 in Appendix B. However, there is only one sector, the service sector, in the CGE model to represent all these. The starting point is to take the projection of the service sector output from the CGE model. However, the CGE model runs in monetary values, not in physical quantity. Therefore, the growth of this value is applied in the TIMES model. Note that price in the CGE model is kept 1 for the base year, which is 2012. The change in prices in the model serves as a price index. Let us define the output value, its growth rate and price indices as, QACGE; GrCGE, PICGE, respectively.

The demand for energy and corresponding growth rate in the TIMES model are defined as DTIMES and GrTIMEs. Demand for energy in the TIMES model is in energy unit (million tons of coal equivalent). We used sub-sectoral and technological energy consumption shares in the existing TIMES to decompose the service sector energy demand projected by the CGE model. This is explained by the equations below:

$$
\begin{aligned}
& S H_{i, c, t}=\frac{Q D_{\mathrm{TIMES}, i, c, t}}{\sum_{c} Q D_{\mathrm{TIMES}, i, c, t}} \\
& Q A_{C G E, i, c, t}^{\prime}=Q A_{C G E, i, t} * S H_{i, c, t} \\
& G r_{\mathrm{TIMES}-C G E, i, c, t}^{\prime}=\frac{Q A_{C G E, i, c, t}^{\prime}}{Q A_{C G E, i, c, t-1}^{\prime}} \\
& Q D_{\mathrm{TIMES}-C G E, i, c, t}^{\prime}=G r_{\mathrm{TIMES}-C G E, i, c, t}^{\prime} * Q D_{\mathrm{TIMES}, i, c, t-1}
\end{aligned}
$$


Subscripts i, c and t represent the sector, technology and year, respectively. SH refers to share. $G r^{\prime}$ denotes the growth rate.

Two issues are important here to note. First, all technologies and sub-sectors use the same growth rate of the aggregated service sector output from the CGE model. In reality, energy demand in different sub-sectors in the TIMES model grows at different rates. Different energy rates of various technologies within the sub-sectors will grow differently due to assumed technological development and policy prescription. If we start the linking process by using CGE outputs to TIMES, all these sub-sectoral and technological features will be lost. Second, energy demand in the TIMES model accounts forecasts of international prices of energy commodities, whereas price indices provided by the CGE model are domestic prices. To reflect these features, at least in some aggregated way or weighted averaged form, it would be appropriate to start the linkage from the TIMES model. Meaning that energy demand in the CGE model is first adjusted using energy demand growth of the TIMES model (in the first run of the linkage).

TIMES is an engineering model. It does not project the prices of energy commodities directly. However, it determines the unit cost of energy service delivery. These unit costs (which are average costs) reflect the prices of corresponding energy commodities. One advantage of the TIMES model is that it allows various networks to deliver energy services to complete based on their service delivery cost (or network price). For example, to meet cooking demand for the restaurant sub-sector (an activity in the service sector), different networks for energy carriers (e.g., LPG produced in petroleum refinery and transported by trucks, natural gas processed in gas plant and supplied through pipeline, fuelwood harvested from natural forests and supplied through trucks, electricity supplied through distribution network) compete. It finds the optimal mix of these networks to ensure the least cost to deliver a unit of energy service (heat for cooking here). While finding the optimal solution, environmental or policy constraints can be incorporated. For example, if the policy is to adopt more and cleaner cooking, the model can incorporate it by setting a higher share for LPG, natural gas or electricity instead of wood fuel or biomass for cooking.

The base year for the CGE is 2012, whereas it is 2015 in the TIMES model. The TIMES model used historical data for the 2012-2015 period, whereas it uses CGE projection afterward. 


\section{C.1.2 Energy Demand in the Residential Sector}

Household income and population growth are the main drivers for energy consumption in the TIMES model. Although energy price is the main factor for household fuel choice, the TIMES model does not take pricing information in the demand side. The pricing information is used in the supply side while the least-cost mix of energy supply network or channels is determined for the household. Household energy demand in the TIMES model is disaggregated by end-use energy services, such as lighting, space heating, cooling, electronic appliances, etc. For each end-use service delivery multiple energy networks or channels are available (please recall the restaurant cooking case mentioned above). Household income growth and population growth rates coming from the CGE model replace the corresponding growth rates already present in the TIMES model before the linkage. The rest of the methodology to project the demand for fuels in the household sector is the same for different end-use energy services are the same as discussed in TIMES model description in Appendix B. As discussed above in the service/commercial sector, the end-use and technology-specific features available in the TIMES model are reflected in the CGE model by starting the model runs with TIMES and adjusting the growth rates of fuels in the CGE to have the same rates in the TIMES model at the aggregated level. The TIMES model also disaggregates households between rural and urban categories. This is because energy demand patterns and fuel mix are different between urban and rural areas. For example, urban households use more electricity and LPG, whereas rural households tend to use more biomass. The household income projected by the CGE model at the national level is decomposed into rural and urban categories for the purpose of using it in the TIMES model. It is done as follows:SHE$E_{r, y}^{T I M E S}=\frac{H E_{r, y}^{T I M E S}}{H E_{y}^{T I M E S}}$

$$
\begin{gathered}
H E_{r, y}^{T I M E S-R}=S H E_{r, y}^{T I M E S} *\left(1-\gamma_{y}^{T I M E S}\right) * H E_{y}^{C G E} \\
\gamma_{y}^{T I M E S}=\frac{T E_{\text {Auto,y }}^{\text {TIMES }}}{H E_{y}^{\text {TIMES }}}
\end{gathered}
$$

Subscript $r$ refers to rural or urban; y refers to year. Superscripts 'TIMES' and 'CGE' refer to values coming from TIMES and CGE models respectively. Note that household energy consumption in TIMES and CGE are substantially different because of the difference of definition of households in these two models. In CGE, a household includes fuel consumption by private transportation (e.g., car, motorcycle), whereas all transport-related energy consumption is included in the transport sector in the TIMES model. Therefore, we introduce 
$\gamma$ in the equation block above, which is the share of private transportation energy consumption to total household energy consumption. The total household energy consumption derived from the CGE model is decomposed into different end-use types, using the shares of various enduse services to the total energy consumption in the households in the TIMES model. It is reflected in the equations below:

$$
\begin{gathered}
H E_{e, r, y}^{T I M E S-R}=S H E_{e, r, y}^{T I M E S} * H E_{r, y}^{T I M E S-R} \\
\text { where, } \\
S H E_{e, r, y}^{T I M E S}=\frac{H E_{e, r, y}^{T I M E S}}{H E_{r, y}^{T I M E S}}
\end{gathered}
$$

Subscript e refers to end-use services, such as lighting, space heating, hot water, electronic devices (TV, cellphone, radio, etc.). Once the total energy service demand is known for an enduse, say cooking, the TIMES model determines the optimal mix of fuels to meet the total energy service demand in that particular end-use type.

\section{C.1.3 Energy Demand in the Industry Sector}

As a bottom-up model, the TIMES model is technological-rich. For the industry sector, several sub-sectors including ferrous metal, non-ferrous metal, non-metallic, chemical industry and other manufacturing industries, are considered, with around 350 technologies. When compared to the CGE model, the chemical products sector, ferrous metal and non-ferrous metal sectors are analyzed in this version of the CGE model. Two kinds of information generated from the CGE are good for the TIMES model: First, the energy service demand driven by GDP is exogenous in the TIMES model, the demand analysis for industry products from the CGE model will add valuable information for the TIMES model. Second, typical fuels in the China CGE (coal/crude oil and gas/gas/petroleum products/Electricity) bring more information for the TIMES model.

We take the sub-sectoral and technological energy consumption shares in the existing TIMES to decompose the sub-sector industry products demand analyzed by the CGE model, which is further explained by the equations below: 


$$
\begin{aligned}
& S H_{i, p, t}=\frac{Q D_{\mathrm{TIMES}, i, p, t}}{\sum_{p} Q D_{\mathrm{TIMES}, i, p, t}} \\
& Q A_{C G E, i, p, t}^{\prime}=Q A_{C G E, i, t} * S H_{i, p, t} \\
& G r_{\mathrm{TIMES}-C G E, i, p, t}^{\prime}=\frac{Q A_{C G E, i, p, t}^{\prime}}{Q A_{C G E, i, p, t-1}^{\prime}} \\
& Q D_{\mathrm{TIMES}-C G E, i, p, t}^{\prime}=G r_{\mathrm{TIMES}-C G E, i, p, t}^{\prime} * Q D_{\mathrm{TIMES}, i, p, t-1}
\end{aligned}
$$

SH is the share of specific industry product. $G r^{\prime}$ Denotes the growth rate. Subscripts i, $Q D$ represents for the quantity in demand of product $p$ in year $t$. Where, $\mathrm{p}$ and $\mathrm{t}$ represent sub-sector, industry product and year, respectively.

In the Chemical sector, for example, products in TIMES include Ammonia /Ethylene/Soda/Caustic Soda/Other Chemicals and average 5-9 techs for each product produced. And in CGE, there is one specific chemical sector. In this case, we use the Weighted Average growth rate for each kind of commodity in the Chemical sector. For non-metallic products, the TIMES model considered cement/lime/glass/bricks/other with detailed technologies for each product, respecting to total non-metallic products in the CGE model. Besides of the weighted average growth rate adjustment, the unit in TIMES is not million tons, which is an energy-based unit, not directly consistent with the unit for a product like glasses. The unit transforms for consistency is an additional work here for the non-metallic products.

\section{C.1.4 Energy Demand in the transportation sector}

The transportation sector energy demands in the TIMES model are estimated by mode: road transportation, railway transportation, water transportation and air transportation. For road transportation, private vehicles with different fuels, buses with different fuels, and trucks of different scales are considered. In the CGE model, private transportation (e.g., transport services used by households) is accounted in the household sector, whereas energy consumption in all transport activities is accounted in the transport sector in the TIMES model. The driver for passenger transportation is household income, whereas the demand for freight transportation is GDP or sectoral outputs. 